\title{
Flora da Bahia: Leguminosae - Centrosema (Papilionoideae: Phaseoleae)
}

\author{
Kamilla Lopes Barreto ${ }^{1, a}$, Moabe Ferreira Fernandes ${ }^{1,2^{*}}$ \& Luciano Paganucci de Queiroz ${ }^{1, b}$ \\ ${ }^{1}$ Programa de Pós-Graduação em Botânica, Universidade Estadual de Feira de Santana, Departamento de Ciências \\ Biológicas, Feira de Santana, Bahia, Brasil. \\ ${ }^{2}$ Programa de Pós-Graduação em Sistemática, Uso e Conservação da Biodiversidade, Universidade Federal do \\ Ceará, Departamento de Biologia, Fortaleza, Ceará, Brasil.
}

\begin{abstract}
Resumo - É apresentado o tratamento taxonômico do gênero Centrosema (Leguminosae) para o estado da Bahia, Brasil. São reconhecidas 15 espécies, o que representa 50\% das espécies de Centrosema registradas no Brasil. O tratamento inclui chaves de identificação, descrições, ilustrações, comentários gerais e mapas de distribuição geográfica das espécies na Bahia.
\end{abstract}

Palavras-chave adicionais: Fabaceae, florística, Leguminosae, Nordeste, Papilionoideae, Taxonomia.

\begin{abstract}
Flora of Bahia: Leguminosae - Centrosema (Papilionoideae: Phaseoleae)) - The taxonomic treatment of Centrosema (Leguminosae) from the State of Bahia, Brazil, is presented. Fifteen species are recognized, which represents $50 \%$ of the Centrosema species recorded in Brazil. The treatment includes keys to identification, descriptions, illustrations, general notes and geographic distribution maps for the species in Bahia.
\end{abstract}

Additional keywords: Fabaceae, floristics, Leguminosae, Northeast Brazil, Papilionoideae, Taxonomy.

Leguminosae compreende aproximadamente 20.000 espécies e 770 gêneros, que são componentes ecologicamente importantes em termos de diversidade e abundância em praticamente todos os biomas e regiões globais (LPWG 2017). A família é bastante diversa morfologicamente e, devido à grande divergência, principalmente em termos de morfologia floral, seus representantes foram tratados por alguns autores (e.g., Cronquist 1981) em três famílias distintas (Caesalpiniaceae, Mimosaceae e Papilionaceae). Caracteres diagnósticos para a família incluem folhas alternas, compostas e com estípulas, flores com ovário súpero, unilocular, além de frutos do tipo legume (LPWG 2017). Leguminosae está entre as famílias mais diversas em praticamente todos os domínios fitogeográficos do Brasil, contribuindo também para os elevados índices de endemismo relacionados à flora do país (BFG 2015). Adicionalmente, é a família mais rica na flora no estado da Bahia, onde ocorrem 915 espécies e 148 gêneros, além de uma grande quantidade de subespécies e variedades (Flora do Brasil 2020, em construção).

Atualmente, Leguminosae é dividida em seis subfamílias (Caesalpinioideae, Cercidoideae, Detarioideae, Dialioideae, Duquepatioideae e Papilionoideae), das quais Papilionoideae é a mais representativa, reunindo mais que $70 \%$ da diversidade total de espécies (LPWG 2017). Das 28 tribos tradicionalmente reconhecidas em Papilionoideae, Phaseoleae (aproximadamente 1500 espécies e 84 gêneros) recebe destaque por englobar grande parte dos grãos

\footnotetext{
*Autor para correspondência: moabeffernandes@gmail.com; aklopesbarreto@gmail.com; bluciano.paganucci@gmail.com Editor responsável: Alessandro Rapini

Submetido: 7 maio 2020; aceito: 19 nov. 2020

Publicação eletrônica: 27 nov. 2020; versão final: 30 nov. 2020
}

economicamente importantes utilizados na alimentação humana e animal, como os diferentes tipos de feijões (gêneros Phaseolus L. e Vigna Savi) e a soja [Glycine max (L.) Merr.]. De forma geral, membros da tribo são geralmente reconhecidos pelo caule volúvel, raramente ereto ou prostrado, folhas pinadas, trifolioladas e estipeladas, inflorescências em pseudorracemos, base do ovário rodeada por um disco nectarífero e frutos deiscentes (Lackey 1981). As espécies de Centrosema, foco deste trabalho, distinguem-se dos demais gêneros em Phaseoleae por apresentarem estandarte largo, geralmente calcarado na porção dorsal, aurículas das alas pubescentes e estigma truncado, além de cálice campanulado e pétalas da carena menores, com fruto plano-compresso (Williams \& Clementes 1990; Duno de Stefano et al. 2008).

Centrosema (DC.) Benth., Comm. Legum. Gen.: 53. 1837.

Trepadeiras herbáceas ou lenhosas, volúveis, ou ervas prostradas ou decumbentes; microtricomas uncinados nos ramos jovens, pecíolo, raque foliar, nervuras dos folíolos e eixos da inflorescência; ramos glabrescentes ou indumentados. Estípulas persistentes, raramente caducas, triangulares, ovadas ou lanceoladas. Folhas pecioladas; geralmente pinadas 3-folioladas, raramente digitadas 3-folioladas, 1-7folioladas; raque, se presente, canaliculada; estipelas persistentes ou caducas, lineares ou linear-lanceoladas; folíolos peninérvios, venação secundária broquidódroma. Inflorescências pseudorracemos axilares, geralmente com uma flor aberta de cada vez; pedúnculo fractiflexo; brácteas de primeira e de segunda ordens estriadas, semelhantes às estípulas, bractéolas 2, maiores do que as brácteas, imbricadas no botão, opostas na antese, adpressas na base do cálice, ovadas, oblongas ou lanceoladas; pedicelos mais curtos que o cálice; botões oval-elipsoides. Flores 1,5$3,5 \mathrm{~cm}$ compr., ressupinadas pela torção do pedicelo; 
cálice curtamente campanulado, glabrescente ou indumentado, 4-laciniado, lacínias de comprimento semelhante ou a inferior (vexilar) muito mais curta ou a superior (carenal) muito mais longa que as demais, 2 lacínias superiores variadamente unidas; pétalas lilás, roxas, magentas ou brancas, unguiculadas, estandarte geralmente com feixe branco ou creme, suborbicular ou orbicular, calcarado ou não no dorso próximo à base, externamente indumentado; alas falcadas ou sigmoides, auriculadas, indumentadas; pétalas da carena semiorbiculares, curvadas, indumentadas; androceu diadelfo, 9 estames soldados em bainha e estame vexilar livre, anteras uniformes, oblongo-elípticas; disco nectarífero cilíndrico, não lobado; ovário séssil, indumentado, mais de 4 óvulos, estilete curvo, achatado ou cilíndrico, glabrescente, estigma truncado ou emarginado, ciliado ou não. Legumes elasticamente deiscentes, lineares, retos ou falcados, planocompressos, rostrados, pouco ou bem desenvolvidos, 0,5-3 cm compr., margens espessadas; valvas coriáceas, pubérulas a glabrescentes. Sementes 4-8, não compressas, oblongo-elipsoides; testa coriácea, castanha, na maioria das vezes com manchas de cor mais escura; hilo curto, oblongo a circular.

Centrosema é um gênero de distribuição neotropical que inclui aproximadamente 35 espécies. O Brasil é considerado o principal centro de diversidade do gênero. Aproximadamente 30 espécies ocorrem no país, sendo nove endêmicas, geralmente associadas a florestas estacionais, cerrados, áreas inundadas e pastagens (Souza 2019). Neste trabalho, identificamos a ocorrência de 15 espécies e duas variedades para o estado da Bahia, representando $50 \%$ de toda a diversidade registrada para o Brasil.

\section{Chave para as espécies}

1. Raque ausente ou inconspícua, até $0,4 \mathrm{~cm}$ compr.

2. Folíolo 1, base sagitada; pecíolo alado

2'. Folíolos 3-5, base não sagitada; pecíolo não-alado.

3. Folíolos com ápice acuminado, 50-90 pares de nervuras secundárias

11. C. sagittatum

3'. Folíolos com ápice obtuso, emarginado ou mucronado, 6-17(-20) pares de nervuras secundárias.

4. Folíolos geralmente lanceolados, raramente elípticos; cálice com lacínia superior reta

14. C. venosum

4'. Folíolos obovados ou elípticos; cálice com lacínia superior curvada

3. C. bracteosum

1'. Raque presente, $0,5-14 \mathrm{~cm}$ compr.

5. Folíolo terminal oval a rômbico; pétalas brancas

8. C. plumieri

5'. Folíolo terminal nunca rômbico; pétalas lilás a roxas, raramente rosa a brancas.

6. Todas as lacínias do cálice maiores que as bractéolas.

7. Folíolos lineares a oval-lanceolados; flores pequenas, 1-3,2 cm compr.; lacínias do cálice desiguais .

7. C. pascuorum

7'. Folíolos elípticos a ovais; flores grandes, 2,1-5,8 cm compr.; lacínias do cálice de tamanho uniforme 15. C. virginianum

6'. Pelo menos a lacínia inferior e as laterais menores que as bractéolas.

8. Estandarte calcarado inconspícuo no dorso, externamente seríceo

8'. Estandarte calcarado conspícuo no dorso, externamente piloso.

12. C. sericiflorum

9. Caule lenhoso; folíolos cartáceos ou coriáceos; estandarte magenta.

10. Ramos jovens, pecíolo e raque pubescentes a tomentosos; folíolos com face adaxial rugosa ....

2. C. arenarium

10'.Ramos jovens, pecíolo e raque glabrescentes, folíolos com face adaxial ligeiramente reticulada 5. C. coriaceum

9'. Caule não lenhoso; folíolos membranáceos a cartáceos; estandarte lilás a roxo.

11. Folíolos 3-5, ápice arredondado ou truncado; frutos falcados, 2,8-4 cm compr.

10. C. rotundifolium

11'. Folíolos 3, ápice agudo, acuminado, obtuso ou mucronado; frutos retos, 8-22 cm compr.

12. Folíolo terminal triangular, base hastada

13. C. schottii

12'. Folíolo terminal não triangular, base obtusa.

13. Folíolos esparsamente pilosos; inflorescências mais curtas que a folha adjacente; brácteas oval-orbiculares

4. C. brasilianum

13'. Folíolos pilosos a pubescentes; inflorescências mais longas que a folha adjacente; brácteas oval-lanceoladas.

14. Estipelas 4-6 mm compr.; frutos 15,5-22 cm compr., valvas com pontuações translúcidas

6. C. macrocarpum

14'. Estipelas 1,5-3 $\mathrm{mm}$; frutos 13,4-14 cm compr., valvas sem pontuações translúcidas

9. C. pubescens 
1. Centrosema angustifolium (Kunth) Benth., Comm. Legum. Gen.: 54. 1837.

Figuras 1A, 3A, e 8 .

Nome popular: cunhã.

Trepadeira lenhosa, volúvel, ca. $60 \mathrm{~cm}$ alt.; ramos jovens, pecíolo e raque esparsamente pilosos, tricomas setiformes, esparsos. Estípulas 3-5,2 × 1-2 mm, ovallanceoladas, acuminadas, face externa pilosa, persistentes. Folhas 6,5-11,8 cm compr., (sub)palmadas; pecíolo $0,7-5,4 \mathrm{~cm}$ compr.; raque $0,1-$ $0,4 \mathrm{~cm}$ compr., ausente ou inconspícua; estipelas $1,8-$ $4,1 \times 0,1-0,5 \mathrm{~mm}$, linear-triangulares, face externa esparsamente pilosa, caducas; folíolos 3, cartáceos 4,3$9,5 \times 0,2-0,9 \mathrm{~cm}$, o terminal com tamanho similar ao par basal, linear-lanceolados, raramente oblongos, ápice acuminado, base aguda, os laterais ligeiramente assimétricos, esparsamente pilosos em ambas as faces, venação reticulada, 50-90 pares de nervuras secundárias. Pseudorracemos 3-4,3 cm compr., mais curtos que a folha adjacente; brácteas e bractéolas puberulentas, oval-lanceoladas, brácteas de segunda ordem 3,5-8 × 2,1-4 mm, bractéolas 11-15 × 5-6 mm, assimétricas; pedicelos $0,3-0,9 \mathrm{~mm}$ compr. Flores lilás, 2,9-3,5 cm compr.; cálice 8-10 mm compr., tubo 4-5× 4,5-6,5 mm, face externa pilosa, tricomas finos e eretos, face interna glabrescente, lacínias 4 , a superior 6-7 mm compr., as laterais 2-3,2 mm compr., a inferior 3-4 mm compr., unida até mais da metade da base, bífida; estandarte 2,2-2,8 $\times 3,1-3,5 \mathrm{~cm}$, orbicular, face externa pilosa, com tricomas retos e curtos, face interna glabrescente, calcar 1,5-2 mm compr.; alas 2,1-2,6 cm compr., falcadas, onduladas; pétalas da carena 1,8-2,3 $\times$ 1-1,3 cm, face externa pilosa a glabrescente, face interna esparsamente pilosa; androceu 3-3,6 cm compr., glabrescente, bainha estaminal 2,4-3,1 cm compr., filetes livres por 5-6 mm compr., anteras $1-1,2 \times 0,8-1$ mm, oblongo-elípticas; pistilo 3-3,3 cm compr., ovário 1,7-2 × 9-10 mm, séssil, piloso, estilete 1,2-1,3 cm compr., pubérulo, estigma truncado e ciliado. Legumes 9-13 × 0,3-0,4 cm, retos, margens reto-onduladas, base aguda, valvas castanho-claras a vináceas, esparsamente pilosas, com tricomas curtos; sementes 4-4,5 × 1-2 $\times$ 1,9-2 mm, oblongas, testa coriácea, castanho-escura, negra quando seca, hilo 1,5-2 mm compr., oblongo.

Ocorre do México até o Paraguai, incluindo todas as Regiões do Brasil (Schultze-Kraft et al. 1990; Souza 2019). D1, D10, E9, F6 e G2: cerrados, campos rupestres e florestas sobre tabuleiros costeiros, associada a solos arenosos ou rochosos. Floresce durante o ano inteiro, com maior intensidade entre abril e junho, e frutifica entre fevereiro e maio. A antese tem início em torno das 6:00 e as flores se mantêm abertas até às 17:00.

Material selecionado - Barreiras, estrada de chão para

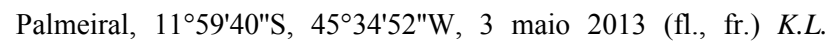
Barreto et al. 76 (HUEFS); Cocos, fazenda Trijunção, estrada para o Guará, próximo à caixa d'água, $14^{\circ} 45^{\prime} 15^{\prime \prime} \mathrm{S}, 45^{\circ} 55^{\prime} 15^{\prime \prime} \mathrm{W}, 11 \mathrm{dez}$. 2001 (fl.), M.L. Fonseca et al. 3060 (IBGE); Conceição do Jacuípe, margem da BR-101, $12^{\circ} 18^{\prime} 60^{\prime \prime} \mathrm{S}, 38^{\circ} 45^{\prime} 59^{\prime \prime} \mathrm{W}$, abr. 1974 (fl.), G.C.P.
Pinto 42261 (ALCB); Rio de Contas, entre Rio de Contas e Jussiape, $13^{\circ} 35^{\prime} \mathrm{S}, 41^{\circ} 45^{\prime} \mathrm{W}$, T.B. Cavalcanti et al. 332 (SPSF); Rio Real,

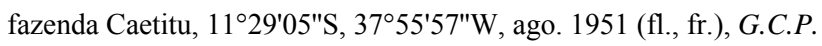
Pinto s.n. (ALCB 6218).

Centrosema angustifolium pode ser reconhecida principalmente pelas folhas palmadas (raque ausente ou inconspícua) e pelos folíolos linear-lanceolados, raramente oblongos, com muitas nervuras secundárias dispostas paralelamente. Os folíolos estreitos assemelham-se àqueles de C. pascuorum, da qual se diferencia por apresentar raque foliar inconspícua ou ausente (vs. bem desenvolvida em C. pascuorum), maior quantidade de nervuras secundárias nos folíolos ( $>50$ vs. $<20$ pares) e flores maiores $(2,9-3,5 \mathrm{~cm}$ compr. vs. 1-2,3 cm compr.).

2. Centrosema arenarium Benth., Comm. Legum. Gen.: 55. 1837.

Figura 1B, C, 3B-D e 8.

Nome popular: feijão-do-mato.

Trepadeira lenhosa, volúvel, ou subarbusto ereto, 1-2,5 m alt.; ramos jovens, pecíolo e raque pubescentes a tomentosos, tricomas curtos, sinuosos e adpressos. Estípulas 2-7 × 1-3 mm, oval-triangulares, acuminadas, face externa pilosa, persistentes. Folhas 3-12 cm compr., pinadas; pecíolo 0,6-3,2 cm compr.; raque $0,5-1,7 \mathrm{~cm}$ compr.; estipelas $2,3-8 \times 0,1-0,5$ $\mathrm{mm}$, linear-triangulares, face externa esparsamente pilosa, geralmente caducas; folíolos 3, cartáceos a coriáceos, 3,1-9,5 × 1-4,5 cm, o terminal 2 vezes maior que os basais, ovais a elípticos, às vezes orbiculares, ápice obtuso ou agudo, geralmente mucronado, base obtusa, os laterais ligeiramente assimétricos, face adaxial rugosa, pilosa, face abaxial pubescente a tomentosa, principalmente ao longo das nervuras secundárias, venação reticulada, 5-13 pares de nervuras secundárias. Pseudorracemos 2,8-7,3 cm compr., mais curtos que a folha adjacente; brácteas e bractéolas esparsamente pilosas, brácteas de segunda ordem 4-8 × 2-4,5 mm, oval-lanceoladas, bractéolas 8-15 × 4-6 $\mathrm{mm}$, elíptico-oblongas, assimétricas; pedicelos 0,5-1,2 $\mathrm{cm}$ compr. Flores rosa, 2,5-5 cm compr.; cálice 7-14 mm compr., tubo 4-7 $\times 5-8 \mathrm{~mm}$, face externa pilosa, tricomas finos e eretos, face interna pilosa a glabrescente, lacínias 4 , a superior 2-5, $1 \mathrm{~mm}$ compr., as laterais 2-4 $\mathrm{mm}$ compr., a inferior 2-9 mm compr., bífida; estandarte 1,8-3,1 $\times$ 1,4-3,8 cm, orbicular, face externa pubescente, face interna pilosa a glabrescente, calcar 1,5-2,5 $\mathrm{mm}$ compr.; alas 1,7-2,7 cm compr., falcadas, onduladas; pétalas da carena $1,6-2,5 \times 0,6-1,5 \mathrm{~cm}$, face externa pilosa, face interna esparsamente pilosa; androceu 1,73,8 cm compr., glabrescente, bainha estaminal 1,3-3 cm compr., filetes livres por 4-8 mm compr., anteras 1-1,5 × 0,9-1,2 mm, oblongo-elípticas; pistilo 1,2-2,6 cm compr., ovário 9-20 × 0,5-1 mm, séssil, hirsuto, estilete 0,3-1,3 cm compr., pubérulo, estigma truncado. Legumes 9,3-21,5 × 0,4-0,6 cm, retos, margens onduladas, base aguda, valvas castanho-claras a 

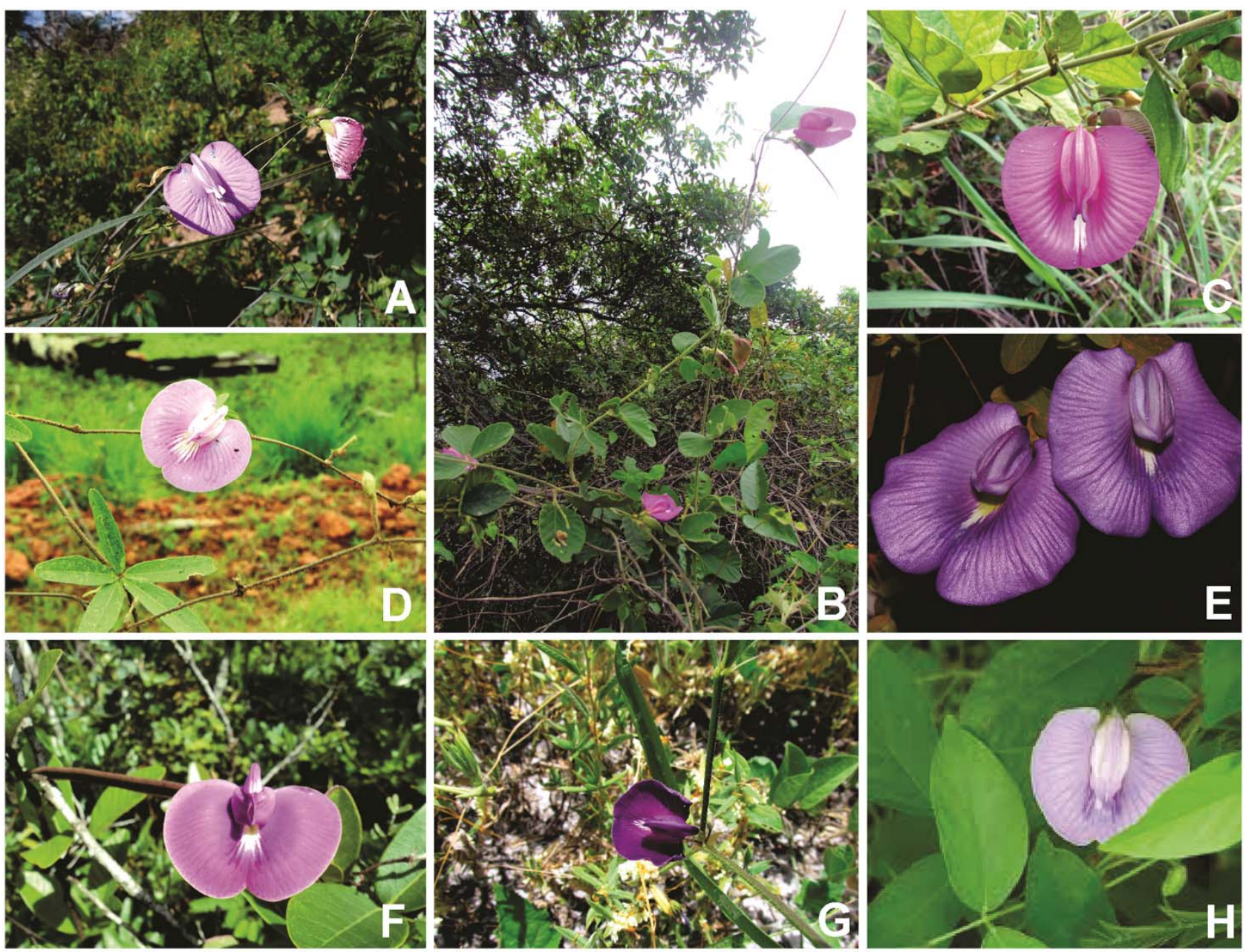

Figura 1. A. Centrosema angustifolium: ramo com inflorescência e folha. B, C. C. arenarium: B- hábito, C- ramo com inflorescência e folha. D. C. bracteosum: ramo com inflorescência e folha. E. C. brasilianum var. brasilianum: ramo com flor e folha. F. C. coriaceum: flor, folha e fruto. G. C. pascuorum: hábito. H. C. pubescens: flor e folha (Fotos: A-C e G- Kamilla Barreto; D e E- Domingos Cardosos; F- Cristiane Snak; H- Réginald Hulhoven).

vináceas, pubescentes, tricomas adpressos, sementes $3-$ $5 \times 3-4 \times 0,8-1,1 \mathrm{~mm}$, cilíndricas ou oblongas, testa coriácea, castanho-escura a vinácea, negra quando seca, hilo 1,5-2 mm compr., oblongo.

Ocorre na América do Sul (Brasil e Paraguai) e América Central (Nicarágua e Panamá; Queiroz 2009). No Brasil, é amplamente distribuída nas Regiões Nordeste, Centro-Oeste, Sudeste e Sul (Souza 2019). B7, B9, C5, C6, C7, C8, D6, D7, E5, E6, E8, E9, F5, F6, F9, G5, H8, I8 e J8: principalmente em caatingas arbustivo-arbóreas, florestas estacionais semideciduais, cerrados, florestas ombrófilas, restingas, campos rupestres e áreas antropizadas, predominantemente associada a solos arenosos. Floresce durante o ano todo e frutifica de novembro a março. A antese tem início em torno das 6:00 e a flores se mantêm abertas até cerca de 17:30.

Material selecionado - Abaíra, estrada Catolés-Abaíra, ca. 5 km de Catolés, 1319"S, 4149'W, 24 nov. 1992 (fl.), W. Ganev 1552 (HUEFS, SPSF); Andaraí, Distrito de Igatu, 12 $53^{\prime} 44^{\prime \prime S}$,

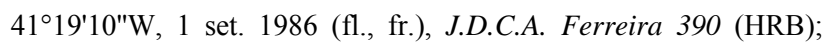
Baixa Grande, $11^{\circ} 52^{\prime} 26^{\prime \prime} \mathrm{S}, 40^{\circ} 06^{\prime} 18^{\prime \prime} \mathrm{W}, 2$ set. 1980 (fl.), R.P. Orlandi 288 (CEPEC, HRB, HUEFS, NY, RB, SPSF); Barreiras,
BR-242, Km 1052, Brasília-Fortaleza, 1209'10"S, 4459'24"W, 29 set. 2009 (fl., fr.), L. Coradin et al. 1196 (CEN, CEPEC, HRB, HUEFS, NY, RB, SPSF); Caen, $11^{\circ} 08^{\prime} \mathrm{S}, 40^{\circ} 25^{\prime} \mathrm{W}, 3$ set. 1981 (fl.), G.C.P. Pinto 31381 (HUEFS); Caetité, Brejinho dos Ametistas,

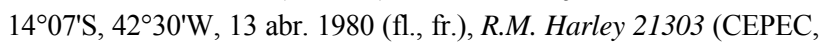
HUEFS, RB); Campo Formoso, 10¹4'34"S, 40¹5'57"W, 14 abr. 2006 (fl.), V.J. Santos 551 (HUEFS); Canavieiras, próximo da fazenda

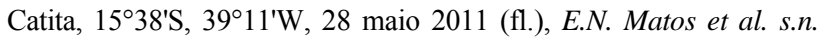
(HUEFS 180445); Feira de Santana, Campus da Universidade Estadual de Feira de Santana, $13^{\circ} 15^{\prime}$ S, 38 $38^{\circ} 58^{\prime} \mathrm{W}, 5$ jul. 1993 (fl.), T.S.N. Sena 6 (HUEFS); Filadélfia, $5 \mathrm{~km}$ na estrada para Pindobaçu, $10^{\circ} 46^{\prime} 20^{\prime \prime} \mathrm{S}, 40^{\circ} 08^{\prime} 55^{\prime \prime W}, 28$ fev. 2000 (fl.), A.M. Giulietti \& R.M. Harley 1877 (HUEFS); Igaporã, 134' $24^{\prime \prime S}, 42^{\circ} 42^{\prime} 51 " \mathrm{~W}, 5$ abr. 1992 (fl.), G. Hatschbach 56635 (MBM); Ipirá, 1209'30"S, 3944'13"W, 18 abr. 1985 (fl.), E.L.P.G. Oliveira 796 (CEPEC); Jacobina, $11^{\circ} 10^{\prime} 51 " \mathrm{~S}, 40^{\circ} 31^{\prime} 06^{\prime \prime W}$, s.d. (fl., fr.), L.M. Guedes et al. 9343 (CEPEC); Jaguarari, fazenda Umburanas, 108'18"S, 40¹3'46"W, 13 abr. 2006 (fl.), P.F.S. Silva 185 (HUEFS); Juazeiro, margem direita do rio São Francisco, próximo ao desembarque da Ilha do Rodeadouro, $09^{\circ} 30^{\prime} \mathrm{S}, 40^{\circ} 30^{\prime} \mathrm{W}, 30$ maio 2011 (fl.), 359 m s.n.m., J.P.B. Nascimento 6 (HVASF); Lençóis, fim da estrada que sai do restaurante de Luís Piedade, 12³3'48"S, 41²3'23"W, 21 ago. 1996 (fl.), A.A. Conceição \& A.A. Grillo 87 (SPSF); Licínio de Almeida, 

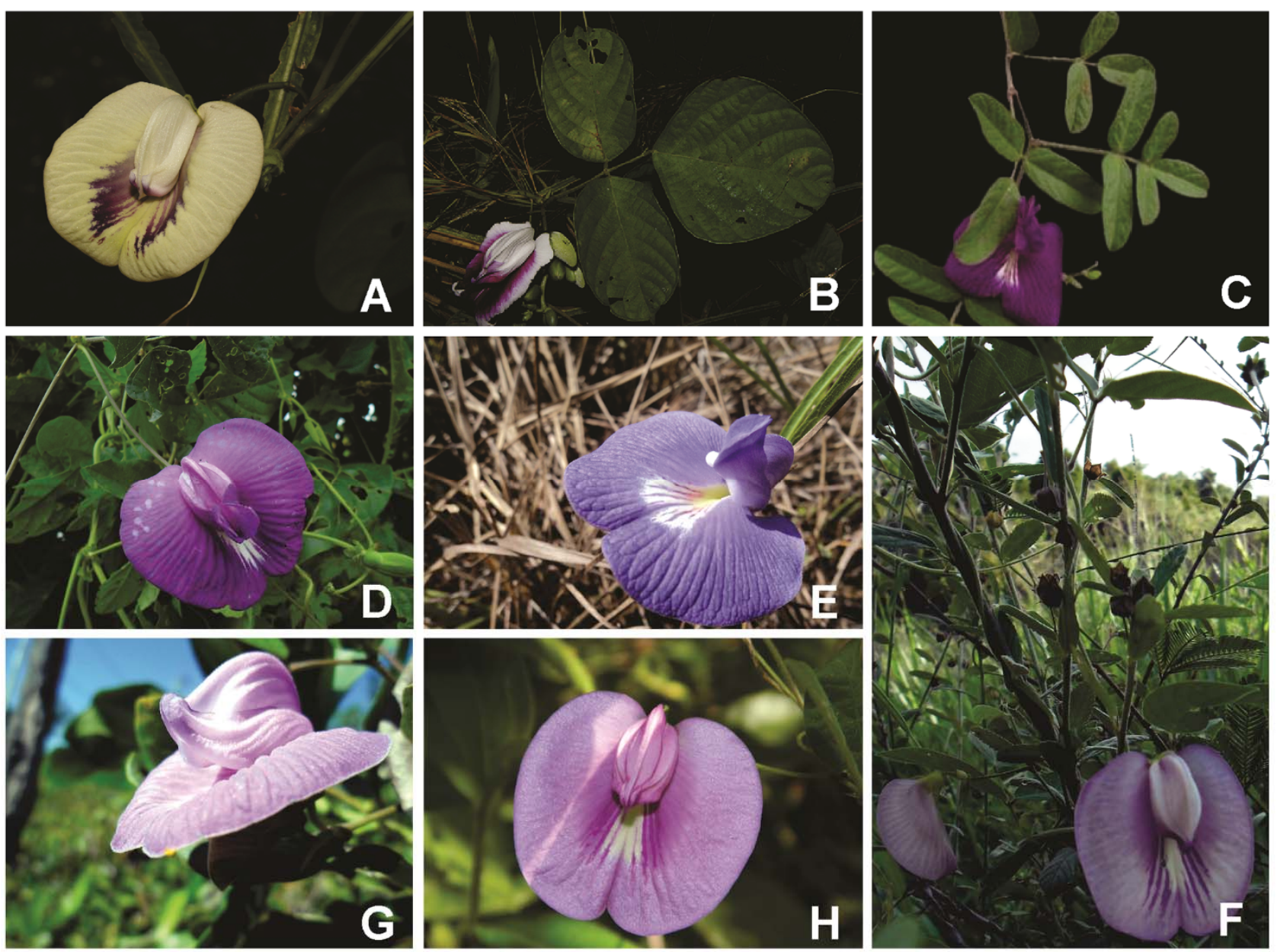

Figura 2. A, B. Centrosema plumieri: A- flor; B- inflorescência e folha. C. C. rotundifolium: inflorescência e folha. D. C. schottii: inflorescência e folha. E. C. venosum: flor. F-H. C. virginianum: F- flor em vista lateral; G- flor; H- hábito (Fotos: A- Domingos Cardoso; BReinaldo Aguiar; C- Wallace São-Mateus; D, F-H- Kamilla Barreto; E- Cristiane Snak.).

Distrito de São Domingos, fazenda São Domingos, 14³3'54"S, 4231'22"W, 11 dez. 2009 (fl.), E. Melo et al. 7473 (HUEFS); Livramento do Brumado, estrada Livramento-Rio de Contas, 3 km da cidade de Rio de Contas, $13^{\circ} 38^{\prime} 35^{\prime \prime S}, 41^{\circ} 50^{\prime} 26^{\prime \prime} \mathrm{W}, 10$ abr. 1999 (fl.), R.C. Forzza et al. 1117 (CEPEC); Monte Santo, $10^{\circ} 27^{\prime} \mathrm{S}, 39^{\circ} 20^{\prime} \mathrm{W}, 20$ fev. 1974 (fl.), R.M. Harley 16414 (CEPEC); Morro do Chapéu, estrada sentido Jacobina, Km 22, $11^{\circ} 24^{\prime} 32^{\prime \prime S}, 41^{\circ} 02^{\prime} 09^{\prime \prime W}, 17$ fev. 2004 (fl.), G.P. da Silva 8475 (CEN); Mucugê, $9 \mathrm{~km}$ a SW de Mucugê, rodovia para Cascavel, terreno próximo ao rio Paraguaçu, $13^{\circ} 02^{\prime} \mathrm{S}, 41^{\circ} 25^{\prime} \mathrm{W}, 5$ fev. 1974 (bot., fl.), R.M. Harley 16035 (CEPEC); Nova Viçosa, $5 \mathrm{~km}$ da rodovia Nova Viçosa-Posto da Mata (BR-101), s.d. (fl.), L.A.M. Silva \& T.S. Santos s.n. (ALCB 9436); Oliveira dos Brejinhos, 12¹9'01"S, 4253'46"W, 16 mar. 1998 (fl., fr.), G. Hatschbach et al. 67787 (HUEFS); Palmeiras, BR-242, 12²6'32,5"S,

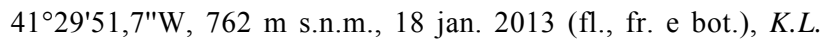
Barreto \& I.M. Souza 28 (HUEFS); Piatã, ca. $1 \mathrm{~km}$ de Brejo de Cima, $13^{\circ} 18^{\prime} 42^{\prime \prime S}, 41^{\circ} 33^{\prime} 45^{\prime \prime} \mathrm{W}, 8$ jan. 2006 (fl., fr.), T.S. Nunes et al. 1455 (HUEFS); Pindobaçu, trilha para Serra da Fumaça, 10³9'55"S, 40²0'34"W, 16 dez. 2008 (f1.), L.A. Sousa 219 (HUEFS); Porto Seguro, 16 $26^{\prime} 60^{\prime \prime} \mathrm{S}, 3^{\circ} 03^{\prime} 52^{\prime \prime} \mathrm{W}, 22$ ago. 1961 (fl., frt.), A.P. Duarte 5965 (RB); Prado, 17²0'28"S, 39¹3'14"S, s.d. (fl.), M. Fonseca 1143 (CEPEC); Rio de Contas, estrada Rio de Contas-Rio da Caixa, Km 13, 13³7'19"S, 4148'06"W, 17 jan. 2004 (fl., fr.), G. Pereira-Silva et al. 8403 (CEN); Santa Brígida, $09^{\circ} 41^{\prime} 48^{\prime \prime S}, 38^{\circ} 13^{\prime} 54^{\prime \prime} \mathrm{W}, 23$ ago. 2005, D.S. Carneiro-Torres et al. 495 (HUEFS); Saúde, 1056'S, 40²5'W, 22 jun. 1987 (fr.), $L$. Coradin et al. 7734 (HUEFS); Sento Sé, $16 \mathrm{~km}$ a NW de Lagoinha (5,5 km a SW de Delfino), $10^{\circ} 22^{\prime} \mathrm{S}, 41^{\circ} 20^{\prime} \mathrm{W}, 4$ mar. 1974 (fl., fr.), R.M. Harley 16686 (CEPEC); Tucano, fazenda Boqueirão, $12^{\circ} 01^{\prime} 33^{\prime \prime S}, 38^{\circ} 38^{\prime} 22^{\prime \prime} \mathrm{W}, 5$ jan. 2006 (fl.), D. Cardoso \& J.M.O. Santos 930 (HUEFS); Umburanas, Distrito de Delfino, $10^{\circ} 22^{\prime} \mathrm{S}, 41^{\circ} 20^{\prime} \mathrm{W}, 4$ mar. 1974 (fl., fr.), R.M. Harley 16686 (IPA); Una, Parque Ecoturístico de Una, próximo à REBIO (Reserva Biológica de Una), $15^{\circ} 18^{\prime} 01^{\prime \prime S}, 39^{\circ} 03^{\prime} 59^{\prime \prime W}$, s.d., J.S. Blanchet 3712 (NY).

Centrosema arenarium se assemelha a $C$. coriaceum pela presença de ramos lenhosos e folíolos coriáceos (Queiroz 2009), distinguindo-se basicamente por apresentar ramos e folíolos pubescentes a tomentosos (vs. glabros em C. coriaceum) e face adaxial dos folíolos rugosa (vs. lisa).

3. Centrosema bracteosum Benth., Comm. Legum. Gen.: 55.1837.

Figuras 1D, 3E, 4A-C e 10.

Nome popular: rabo-de-tatu.

Erva prostrada ou volúvel, ca. 1,5 m alt.; ramos jovens e pecíolo puberulentos. Estípulas $2-5 \times 1,5-$ 2,5 mm, oval-triangulares, acuminadas, face adaxial 

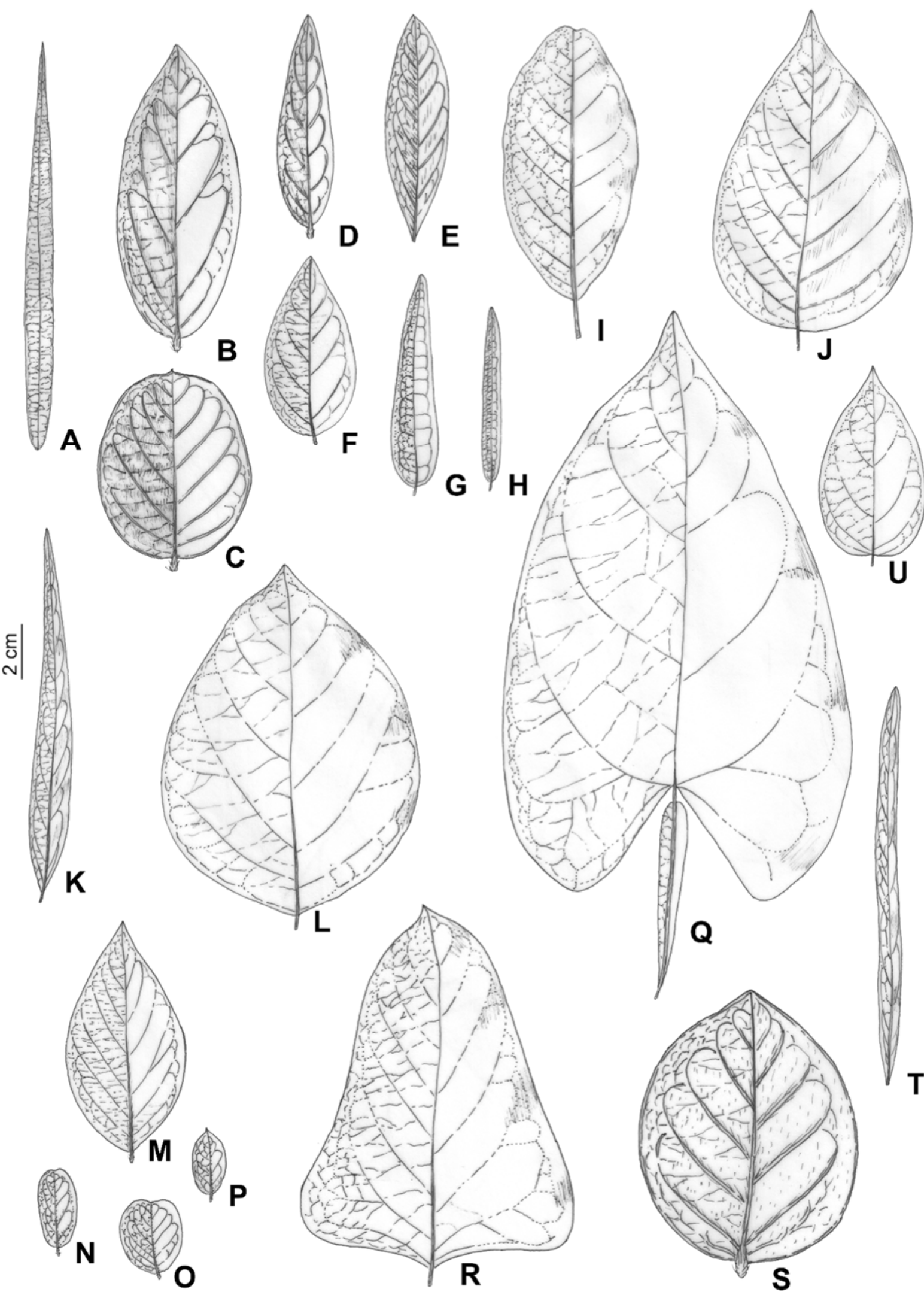
pubérula, persistentes. Folhas 5-10,4 cm compr., digitadas; pecíolo 1,3-4,8 cm compr.; raque ausente; estipelas $2-5 \times 0,6-1 \mathrm{~mm}$, setiforme-triangulares, face externa pubérula; folíolos 3-5, papiráceos a cartáceos, $3,2-10,3 \times 1,2-2,6 \mathrm{~cm}$, obovados ou elípticos, ápice obtuso, emarginado ou mucronado, base aguda, os laterais ligeiramente assimétricos, ambas as faces pilosas a glabrescentes, venação reticulada pouco proeminente em ambas as faces, $6-13$ pares de nervuras secundárias. Pseudorracemos 4,2-7,1 cm compr., maiores que a folha adjacente; brácteas e bractéolas esparsamente pilosas, brácteas de segunda ordem 2,5$10 \times 1,5-6 \mathrm{~mm}$, lanceolado-suborbiculares, bractéolas $10-15 \times 4,5-6,5 \mathrm{~mm}$, elíptico-oblongas, simétricas; pedicelos $0,5-1,3 \mathrm{~cm}$ compr. Flores lilásesbranquiçadas, $2,8-5 \mathrm{~cm}$ compr.; cálice $1,4-2,4 \mathrm{~cm}$ compr., tubo 4-5 × 4,5-7,2 mm, face externa pilosa, face interna glabrescente, lacínias 4 , a superior $11,5-14$ $\mathrm{mm}$ compr., curvada, as laterais 4-6 $\mathrm{mm}$ compr., a inferior 3-6 mm compr., bífida, unida a mais da metade da base; estandarte orbicular 1,4-2,7 × 1,2-2,7 cm, face externa pubescente, face interna glabrescente, calcar 1$4 \mathrm{~mm}$ compr.; alas falcadas, onduladas $1,4-2,3 \mathrm{~cm}$ compr.; pétalas da carena 1,3-1,9 × 0,6-1,4 cm, face externa esparsamente pilosa, face interna glabrescente; androceu 0,9-3,5 cm compr., glabrescente, bainha estaminal $0,7-3 \mathrm{~cm}$ compr., filetes livres por $3-5 \mathrm{~mm}$ compr., anteras 1-1,5 × 0,9-1 mm, oblongo-elípticas; pistilo 1-27 mm compr., ovário 6-12 × 0,8-1 mm, séssil, hirsuto, estilete 4-15 mm compr., piloso, estigma truncado e ciliado. Legumes $6,7-8,3 \times 4-5 \mathrm{~cm}$, retos, rostro $0,5-1,2 \mathrm{~cm}$ compr., margens onduladas, base aguda, valvas castanho-claras, pubérulas; sementes 3,5$6 \times 2-2,5 \times 0,03-0,2 \mathrm{~mm}$, oblongas, testa coriácea, castanho-clara, hilo ca. 1,2 mm compr., oblongo.

Ocorre em cerrados, associada a solos arenosos. No Brasil, ocorre principalmente na Região Centro-Oeste (Distrito Federal, Goiás e Mato Grosso do Sul), mas também no Nordeste (Bahia), Sudeste (Minas Gerais, São Paulo) e Sul (Paraná) do país. (Schultze-Kraft et al. 1990). Também ocorre no leste da Bolívia e no Paraguai (Missouri Botanical Garden - http://www.tropicos.org). D2, E2/3 e G5: na região oeste, em vegetação de cerrado. Floresce de novembro a janeiro, tendo sido encontrada com frutos em janeiro, março, outubro e novembro. A antese tem início em torno das 6:00 e as flores se mantêm abertas até cerca de 17:00.

Material selecionado - Barreiras, ca. $100 \mathrm{~km} \mathrm{~W}$ de Barreiras, Espigão Mestre, 1209'10"S, 4459'24"W, 7 mar. 1972,

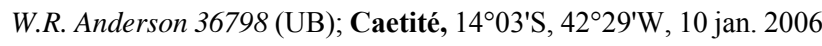
(fl., fr.), T.S. Nunes et al. 1592 (HUEFS); Formosa do Rio Preto,

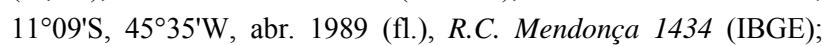
Igaporã, próximo ao trevo para Tanque Novo, $14^{\circ} 07^{\prime} 47^{\prime \prime S}$, 42³0'15"W, 950 m s.n.m, 18 mar. 1995 (fl., fr.), G. Hatschbach \& J.M. Silva 62025 (HUEFS); Santana, 12 ${ }^{\circ} 56^{\prime} \mathrm{S}, 4^{\circ} 03^{\prime} \mathrm{W}, 20$ nov. 1980 (fl.), S.B. Silva 167 (HRB).

Centrosema bracteosum pode ser reconhecida por apresentar folhas digitadas, folíolos obovados ou elípticos, com nervuras pouco proeminentes em ambas as faces, e cálice com lacínia superior lanceolada, maior do que as outras e curvada. As folhas digitadas e trifolioladas são similares às de $C$. venosum, porém a proeminência das nervuras e a forma dos folíolos e lacínias do cálice são suficientes para diferenciar essas espécies. Durante a realização deste trabalho, entretanto, observamos espécimes com morfologia intermediária, sugerindo a necessidade de estudos mais aprofundados a fim de estabelecer limites consistentes entre essas espécies.

\section{Centrosema brasilianum (L.) Benth., Comm. Legum.} Gen.: 54. 1837.

Nomes populares: jequiritirana, brincos-de-princesa, fava-brava, feijão-bravo.

Trepadeira prostrada a volúvel, $1-2 \mathrm{~m}$ alt.; ramos jovens, pecíolo e raque glabrescentes a glabros. Estípulas 2-6 $\times \quad 0,5-1,5 \mathrm{~mm}$, oval-triangulares, acuminadas, face externa glabrescente, persistentes. Folhas 3,6-10 cm compr., pinadas; pecíolo 0,5-2,6 cm compr.; raque 0,5-1,5 cm compr.; estipelas $1-4,5 \times$ $0,1-0,2 \mathrm{~mm}$, linear-triangulares, face externa esparsamente pilosa; folíolos 3 , membranáceos a cartáceos, 2,5-7,7 × 1-4 cm, o terminal oval a linearlanceolado, ápice agudo, obtuso, geralmente mucronado, base obtusa, os laterais ligeiramente assimétricos ou simétricos, face adaxial glabrescente, face abaxial esparsamente pilosa, venação reticulada, 4-15 pares de nervuras secundárias. Pseudorracemos 2,8-5,1 cm compr., mais curtos que a folha adjacente; brácteas e bractéolas glabrescentes, ciliadas nas extremidades, brácteas de segunda ordem 5-7 × 2,5-6 $\mathrm{mm}$, oval-orbiculares, bractéolas 11-16 $\times 5,3-10 \mathrm{~mm}$, elíptico-oblongas, assimétricas; pedicelos $5-12 \mathrm{~mm}$ compr. Flores lilás, 2,2-4,5 cm compr.; cálice 4,5-6,5 $\mathrm{mm}$ compr., tubo 3-5 $\times 3-6 \mathrm{~mm}$, face externa pilosa, tricomas setiformes, face interna esparsamente pilosa, lacínias 4, a superior 1,1-4,5 mm compr., as laterais 1$2 \mathrm{~mm}$ compr., a inferior $1,2-2,5 \mathrm{~mm}$ compr., bífida; estandarte 1,6-3,2 × 2-4 cm, orbicular, face externa pubérula, face interna glabra, calcar 1-2 mm compr.; alas falcadas, onduladas $1,5-2,4 \mathrm{~cm}$ compr.; pétalas da carena $2,1-2,2 \times 1-1,6 \mathrm{~cm}$, face externa pilosa, face interna glabrescente; androceu 2,3-2,8 cm compr., esparsamente piloso, bainha estaminal $1,8-2,3 \mathrm{~cm}$ compr., filetes livres por 5-6 mm compr., anteras $0,8-$ $1,4 \times 0,8-1 \mathrm{~mm}$, oblongo-elípticas; pistilo $1,2-1,5 \mathrm{~mm}$ compr., ovário $11-14 \times 0,5-1 \mathrm{~mm}$, séssil, pubérulo, tricomas adpressos, estilete $8-12 \mathrm{~mm}$ compr., pubérulo, estigma truncado e ciliado. Legumes $8-18 \times 0,3-0,7$ $\mathrm{cm}$, retos, rostro $1,8-2,6 \mathrm{~cm}$ compr., margens onduladas ou retas, base aguda, valvas castanho-claras, pubérulas, tricomas adpressos; sementes 3-4,2 × 2-3 × 0,9-2,2 $\mathrm{mm}$, cilíndricas ou oblongas, testa coriácea, castanhoescura, hilo 0,8-1,5 mm compr., elíptico-oblongo.

Centrosema brasilianum é caracterizada por brácteas oval-orbiculares, folhas com pulvínulos enegrecidos após herborização, flores grandes $(2,2-4,5$ $\mathrm{cm}$ compr.), lacínias do cálice claramente desiguais, 
sendo as laterais mais curtas ou do mesmo tamanho da inferior, e pelas bractéolas grandes encobrindo quase totalmente todas as lacínias do cálice. A forma dos folíolos é semelhante àquela encontrada em $C$. pascuorum e C. virginianum, e as flores possuem dimensões semelhantes às de $C$. virginianum. Entretanto, C. brasilianum diferencia-se dessas espécies por possuir brácteas orbiculares, lacínias do cálice curtas (vs. longas e lineares) e bractéolas recobrindo toda a extensão do cálice. Amshoff (1939) reconhece duas variedades: C. brasilianum var. brasilianum e $C$. brasilianum var. angustifolium.

\section{Chave para as variedades}

1. Folíolos lanceolados a ovais, face adaxial com menos de 10 pares de nervuras secundárias 4.1. C. brasilianum var. brasilianum

1'. Folíolos linear-lanceolados, face adaxial com mais de 10 pares de nervuras secundárias

\subsection{C. brasilianum var. angustifolium}

\subsection{Centrosema brasilianum (L.) Benth. var.} brasilianum, Comm. Legum. Gen.: 54. 1837.

Figuras 1E, 3F, G, e 9.

Encontrada da América Central até o Paraguai, sendo considerada invasora (Williams \& Clements 1990; Queiroz 2009), ocorrendo em todas as Regiões do Brasil (Souza 2019). B6, C5, C6, C7, C9, D6/7, D9, D10, E2, E4, E6, E7, E8, E9, E10, F4, F6, F7, F8, F9, G8, H8 e J8: diferentes tipos de vegetação (caatingas, florestas e campos rupestres), geralmente associados a solos arenosos, e ambientes antropizados. Floresce e frutifica durante o ano todo. A antese tem início em torno das 6:00 e as flores se mantêm abertas até aproximadamente às 17:00.

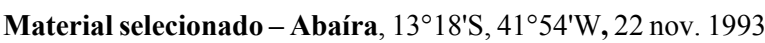

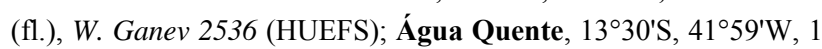
dez. 1988 (fl., fr.), R.M. Harley et al. 26556 (CEPEC, NY, SPSF); Alagoinhas, campus da UNEB, $12^{\circ} 08^{\prime} \mathrm{S}, 38^{\circ} 26^{\prime} \mathrm{W}$, 4 set. 2000 (fl.), N.G. Jesus 416 (CEPEC, HUEFS); Alcobaça, Km 15-20 da rodovia para Itamaraju, $17^{\circ} 31^{\prime} 10^{\prime \prime S}, 39^{\circ} 11^{\prime} 44^{\prime \prime} \mathrm{W}, 11$ ago. 1995 (fl.), G. Hatschbach \& J.T. Motta 62983 (CEPEC, HUEFS, MBM); Andaraí, entroncamento da BR-242, $\mathrm{Km} 30,12^{\circ} 41^{\prime} \mathrm{S}, 41^{\circ} 12^{\prime} \mathrm{W}, 12$ set. 1991 (fl., fr.), L. Coradin et al. 8589 (RB); Anguera, $12^{\circ} 10^{\prime} \mathrm{S}, 39^{\circ} 12^{\prime} \mathrm{W}$, 15 set. 1996 (fl.), E. Melo 1712 (UB); Barra, Dunas do São Francisco, em frente à vila de Ibiraba, no caminho para os Brejos, $10^{\circ} 49^{\prime} 54.2^{\prime \prime S}, 42^{\circ} 56^{\prime} 32.8^{\prime \prime} \mathrm{W}, 16$ fev. 2013 (fl.), K.L. Barreto et al. 39 (HUEFS); Barreiras, Próximo ao hotel Solar das Mangueiras, 1206'55"S, 4504'09"W, 13 abr. 2005 (fl., fr.), L.P. Queiroz 10223 (HUEFS); Bom Jesus da Lapa, estrada Bom Jesus da Lapa-Igaporã,

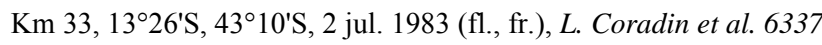
(CEN); Cairu, Ilha de Tinharé, 1329'13"S, 3902'37"W, 9 abr. 1982 (fl., fr.), G.C.P. Pinto et al. 1182 (CEPEC, HRB, HUEFS); Camaçari, $12^{\circ} 56^{\prime} \mathrm{S}, 38^{\circ} 21^{\prime} \mathrm{W}, 4$ fev. 2006 (fl., fr.), D. Cardoso et al. 1109 (HUEFS); Campo Alegre de Lourdes, estrada para Remanso, cerca de $12 \mathrm{~km}$ de Campo Alegre de Lourdes, 09 $35^{\prime} 10^{\prime \prime} \mathrm{S}$, 4254'15"W, 15 jun. 2001 (fl., fr.), T.S. Nunes 428 (ALCB, CEPEC, HUEFS, PEUFR); Casa Nova, Arredores da represa de Sobradinho, $09^{\circ} 31^{\prime} \mathrm{S}, 41^{\circ} 23^{\prime} \mathrm{W}, 8$ set. 1981 (fl., fr.), G.C.P. Pinto 34281 (HUEFS);
Conde, Fazenda do Bu, 1203'24"S, 3741'27"W, 11 set. 1996 (fl.), T. Jost et al. 404 (HUEFS, RB); Entre Rios, Litoral Norte, Massarandupió, a $20 \mathrm{~km}$ de Porto de Sauípe, $11^{\circ} 52^{\prime} \mathrm{S}, 38^{\circ} 02^{\prime} \mathrm{W}, 23$ jul. 2010 (fl.), A.V. Popovkin 719 (HUEFS); Esplanada, Dunas de Baixio, $11^{\circ} 47^{\prime} \mathrm{S}, 37^{\circ} 56^{\prime} \mathrm{W}, 26$ fev. 2000 (fl.), E.P. Queiroz 35 (ALCB); Ibotirama, rodovia Ibotirama-Seabra (BR-242), Km 14, $12^{\circ} 02^{\prime} \mathrm{S}, 43^{\circ} 04^{\prime} \mathrm{W}, 20$ jun. 1987 (fr.), L. Coradin et al. 7645 (CEN, HUEFS); Ilhéus, $9 \mathrm{~km}$ no sul de Ilhéus, estrada Ilhéus-Olivença, Cururupé, $14^{\circ} 51^{\prime} \mathrm{S}, 39^{\circ} 02^{\prime} \mathrm{W}, 29$ nov. 1981(fl.), G.P. Lewis \& A.M. Carvalho 704 (CEPEC); Iramaia, fazenda Leopoldina, 133' $33^{\prime} \mathrm{S}$, 40³'W, 4 abr. 1984 (fl., fr.), J.C.A. Lima \& L.C. Oliveira Filho 107 (CEPEC); Itaberaba, fazenda Itaberaba, $12^{\circ} 30^{\prime} 06^{\prime \prime} \mathrm{S}, 40^{\circ} 05^{\prime} 03^{\prime \prime} \mathrm{W}, 8$ fev. 2008 (fl.), J.L. Ferreira et al. 302 (HUEFS); Itabuna, Br-101,

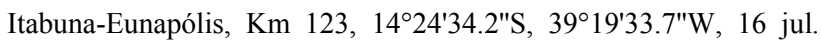
1980 (fl.), K.L. Barreto et al. 62 (HUEFS); Ituaçu, 13²48'50"S, 41 $16^{\prime} 41^{\prime \prime} \mathrm{W}, 23$ jun. 1987 (fl.), L.P. Queiroz et al. 1685 (HUEFS, $\mathrm{MBM}$ ); Ituberá, $13^{\circ} 43^{\prime} \mathrm{S}, 39^{\circ} 08^{\prime} \mathrm{W}, 8$ jun. 2006 (fl.), M. Ramalho et al. s.n. (ALCB 75160); Jandaíra, $11^{\circ} 33^{\prime} \mathrm{S}, 37^{\circ} 47^{\prime} \mathrm{W}, 16$ jul. 2000 (fl.), E.P. Queiroz 72 (ALCB); Jequié, 1351'28"S, 4005'00"W, 26 jan. 1980 (fl.), D. Andrade-Lima 8806 (IPA); Jeremoabo, $10^{\circ} 00^{\prime} 15^{\prime \prime S}, 38^{\circ} 25^{\prime} 59^{\prime \prime} \mathrm{W}, 18$ out. 2009 (fl., fr.), E. Melo et al. 6760 (ALCB); Lençóis, entroncamento e entrada para Lençóis/Itaberaba, BR-242, Km 13, 12 $52^{\prime} \mathrm{S}, 41^{\circ} 30^{\prime} \mathrm{W}, 23$ mar. 2003 (fl., fr.), E. Gross 17 (HUEFS); Livramento do Brumado, estrada Rio de ContasLivramento do Brumado, Km 9, 13³7'S, 41ํํ' W, 17 set. 1992 (fl.), L. Coradin et al. 8652 (RB); Maracás, $6 \mathrm{~km}$ a SW de Maracás, BA026, 13²6'28"S, 40²5'50"W, 26 abr. 1978 (fl.), S.A. Mori et al. 9929 (CEPEC); Maraú, fazenda Taipus de Fora, 135' $35^{\prime \prime} \mathrm{S}, 38^{\circ} 55^{\prime} 50^{\prime \prime} \mathrm{W}$, 24 maio 2009 (fl., fr.), M.L. Guedes et al. 15033 (ALCB, MBM); Mascote, $15^{\circ} 33^{\prime} 47^{\prime \prime S}, 39^{\circ} 18^{\prime} 09^{\prime \prime} \mathrm{W}, 16$ jul. 1980 (fl., fr.), L. Coradin et al. 2922 (CEN, HUEFS, RB); Mata de São João, $12^{\circ} 27^{\prime} 34$ "S, 3756'28"W, 22 jul. 2008 (fl., fr.), F.S. Gomes et al. 68 (ALCB); Miguel Calmon, Piemonte da Diamantina, entorno do Parque de Sete passagens, Boca da Mata, 11 $22^{\prime} 25^{\prime \prime S}, 40^{\circ} 35^{\prime} 14^{\prime \prime} \mathrm{W}, 23$ dez. 2006 (fl., fr.), M.L. Guedes et al. 13224 (ALCB); Morro do Chapéu, $11^{\circ} 40^{\prime} 19^{\prime \prime S}, 41^{\circ} 00^{\prime} 51^{\prime \prime W}, 24$ maio 2008 (bot., fl. e fr.), N. Roque et al. 1822 (ALCB); Mucugê, Parque Municipal de Mucugê, Trilha do Tiburtino, $13^{\circ} 14^{\prime} \mathrm{S}, 41^{\circ} 34^{\prime} \mathrm{W}$, (fl., fr.), J. Costa \& C.N.B. Costa 1332 (HUEFS); Nova Viçosa, 1753'31"S, 39²2'19"W, 21 maio 1980 (f1.), L.A.M. Silva \& T.S. Santos 802 (CEPEC); Palmeiras,

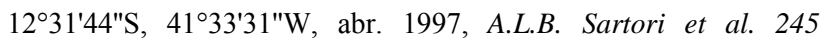
(CEPEC); Rio de Contas, 133' $\mathrm{S}, 41^{\circ} 45^{\prime} \mathrm{W}, 26$ fev. 1989 (fl., fr.), T.B. Cavalcanti et al. 332 (HUEFS); Salvador, Dunas do Abaeté, $12^{\circ} 58^{\prime} \mathrm{S}, 38^{\circ} 30^{\prime} \mathrm{W}, 22$ out. 2005 (fl., fr.), A.L. Cotias et al. s.n. (ALCB 72940); Santo Antônio de Jesus, 12²6'25"S, 3756'11"W, 24 mar. 2006 (fl., fr.), P.O. Rebouças 40 (HUEFS); São Sebastião do Passé, $12^{\circ} 30^{\prime} 45^{\prime \prime S}, 38^{\circ} 29^{\prime} 42^{\prime \prime W}, 17$ out. 1998 (fl.), A.F.S. Nascimento et al. 45 (HRB); Senhor do Bonfim, 10²7'46"S, 40¹1'27"W, 15 ago. 2001 (fl., fr.), T.S. Nunes et al. 607 (HUEFS); Sento Sé, $10^{\circ} 10^{\prime} 18.5^{\prime \prime S}, 41^{\circ} 30^{\prime} 36.6^{\prime \prime} \mathrm{W}, 2$ maio 2012 (fl., fr.), N.M.P. Braga \& R.P. Salomão 37 (IPA); Tanquinho, $8-15 \mathrm{~km} \mathrm{~W}$ do entroncamento de Tanquinho com a BR-116, na BR-324, $12^{\circ} 42^{\prime} \mathrm{S}, 39^{\circ} 43^{\prime} \mathrm{W}, 27$ out. 2004 (fl., fr.), L.P. Queiroz 9684 (HUEFS); Una, 15²17'36"S, $39^{\circ} 04^{\prime} 31^{\prime \prime W}, 3$ jun. 1981 (fl.), J.L. Hage \& E.S. Santos 841 (CEPEC); Utinga, $12^{\circ} 08^{\prime} \mathrm{S}, 41^{\circ} 08^{\prime} \mathrm{W}, 21$ set. 2007 (fl., fr.), P.C. Natividade et al. 11 (HUEFS); Valença, Guaibim. ca. $8 \mathrm{~km}$ na estrada para o atracadouro Porta do Curral, partindo da BA-887, $13^{\circ} 21^{\prime} 57^{\prime \prime S}$, $38^{\circ} 58^{\prime} 36^{\prime \prime W}, 24$ ago. 2002 (fl.), A.M. Carvalho \& C.E.Q. Souza 7218 (CEPEC). 


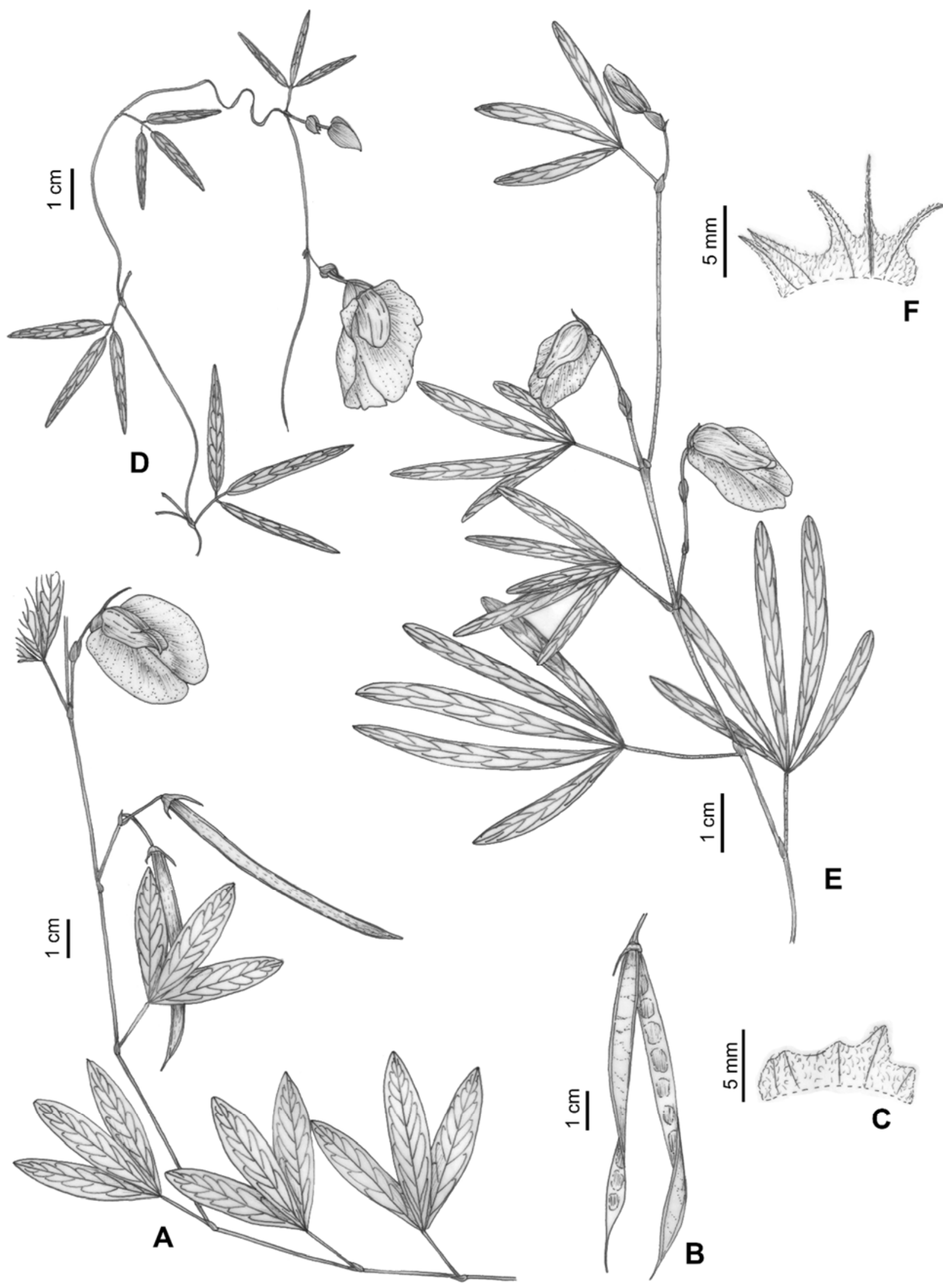

Figura 4. A-C. Centrosema bracteosum: A- ramo com inflorescência e fruto; B- fruto; C- cálice. D. C. brasilianum var. angustifolium: ramo com inflorescência. E, F. C. venosum: E- ramo com inflorescência; F- cálice. (Desenhado por Lucas C. Marinho: A- Nunes et al. 1592; BQueiroz 10032; C- Nascimento 250; D- Queiroz 14475). 
4.2. Centrosema brasilianum var. angustifolium (Kunth) Amshoff, Meded. Bot. Mus. Herb. Rijks Univ. Utrecht 52: 62. 1939.

Figuras 3H, 4D e 9.

Ocorre na região norte da América do Sul. No Brasil, é registrada em todos os estados (Queiroz 2009). Pode ser considerada uma planta invasora, comum em ambientes antropizados (Queiroz 2009; Souza 2019). D5, D7, E7/8, E9 e F6: em caatingas e restingas. Floresce e frutifica de maio a setembro. A antese tem início em torno das 6:00 e as flores se mantêm abertas até aproximadamente às 17:00.

Material selecionado - Alagoinhas, $12^{\circ} 04^{\prime} \mathrm{S}, 38^{\circ} 23^{\prime} \mathrm{W}, 27$ jan. 1993 (fl.), J.A. Kallunki \& J.R. Pirani 381 (HUEFS); Aporá, ca. 12 $\mathrm{km}$ de Crisópolis na estrada para Acajutiba, $12^{\circ} 37^{\prime} 01 " \mathrm{~S}, 39^{\circ} 10^{\prime} 00^{\prime \prime} \mathrm{W}$, 26 ago. 2006 (fl., fr.), L.P. Queiroz \& N.S. Nascimento 4657 (HUEFS); Conceição do Jacuípe, $12^{\circ} 18^{\prime} 00^{\prime \prime} \mathrm{S}, 38^{\circ} 45^{\prime} 59^{\prime \prime} \mathrm{W}$, abr. 1974 (fl., fr.), P. Pinto 42261 (IPA); Feira de Santana, campus da UEFS, $11^{\circ} 33^{\prime} 01^{\prime \prime S}, 42^{\circ} 30^{\prime} 00^{\prime \prime} \mathrm{W}, 28$ out. 2004 (fl.), L.P. Queiroz \& D. Cardoso 10032 (HUEFS, RB); Iaçu, 1250'21"S, 39॰58' $15^{\prime \prime} \mathrm{W}, 20$ fev. 2005 (fl.), F. França et al. 5143 (HUEFS); Itatim, 1243'S, 3942'W, 29 jun. 1996 (fl., fr.), E. Melo et al. 1614 (CEN, HUEFS, IPA); Rio de Contas, $13^{\circ} 35^{\prime} \mathrm{S}, 41^{\circ} 45^{\prime} \mathrm{W}, 26$ fev. 1989 (fl., fr.), T.B. Cavalcanti et al. 332 (HUEFS); Santa Teresinha, $12^{\circ} 47^{\prime} \mathrm{S}, 39^{\circ} 47^{\prime} \mathrm{W}$, 2 jun. 1993 (fr.), L.P. Queiroz et al. 3192 (HUEFS); Serrolândia, $11^{\circ} 18^{\prime} 22^{\prime \prime S}, 40^{\circ} 16^{\prime} 18^{\prime \prime W}, 20$ ago. 1980 (fl., fr.), W.N. Fonseca 257 (CEPEC); Tanquinho, $12^{\circ} 42^{\prime} \mathrm{S}, 39^{\circ} 43^{\prime} \mathrm{W}, 27$ out. 2004 (fl., fr.), L.P. Queiroz 9684 (HUEFS).

5. Centrosema coriaceum Benth., Comm. Legum. Gen.: 54. 1837.

Figuras 1F, 3I, e 10.

Trepadeira ou subarbusto ereto, 0,5-2 m alt.; ramos jovens, pecíolo e raque glabrescentes, tricomas curtos. Estípulas 1-4 × 0,5-3 $\mathrm{mm}$, oval-triangulares, acuminadas, face externa esparsamente pilosa, persistentes. Folhas 4,2-9,2 cm compr., pinadas; pecíolo $0,2-2(-2,6) \mathrm{cm}$ compr.; raque $0,5-2 \mathrm{~cm}$ compr.; estipelas $1-5 \times 0,1-0,5(-0,8) \quad \mathrm{mm}$, setiformetriangulares, face interna pilosa, geralmente caducas; folíolos 3, coriáceos, 3,5-7,1 × 1,7-3,7 cm, ovais a elípticos, ápice obtuso ou emarginado, geralmente mucronado, base obtusa ou emarginada, os laterais ligeiramente assimétricos, face adaxial ligeiramente reticulada, face abaxial esparsamente pilosa principalmente ao longo das nervuras, venação reticulada, 5-10 pares de nervuras secundárias. Pseudorracemos 3-6,2 cm compr., mais curtos que a folha adjacente; brácteas e bractéolas pilosas, brácteas de segunda ordem 2-9 × 1,2-5,9 mm, oval-lanceoladas, bractéolas 9-16 × 3-9 $\mathrm{mm}$, elíptico-oblongas, assimétricas; pedicelos 0,3-1,5 cm compr. Flores rosa, 2,6-4,7 cm compr.; cálice 6,5-11 mm compr., tubo 3,5$6 \times 4,5-11 \mathrm{~mm}$, face externa pubérula, tricomas finos e curtos, face interna glabrescente, com tricomas adpressos, lacínias 4, a superior 4-8,5 mm compr., as laterais 2-5 $\mathrm{mm}$ compr., a inferior 2,5-5,5 $\mathrm{mm}$ compr., bífida; estandarte $2-4 \times 1,9-5 \mathrm{~cm}$, orbicular, face externa pubescente, face interna glabrescente, calcar $1-$
2,5 mm compr.; alas falcadas, onduladas 1,6-3,6 mm compr.; pétalas da carena 1,6-3,7 ×0,9-2,2 cm, face externa pilosa, tricomas adpressos, face interna glabrescente; androceu 1,6-3,5 cm compr., glabrescente, bainha estaminal 1,1-3 cm compr., filetes livres por 0,5-2,9 cm compr., anteras $1-3 \times 0,5-1,8 \mathrm{~mm}$, oblongo-elípticas; pistilo 1,3-2,6 cm compr., ovário $1,2-2,3 \times 8-15 \mathrm{~cm}$, séssil, piloso, estilete $1-1,8 \mathrm{~cm}$ compr., pubérulo, estigma truncado e ciliado. Legumes $8,5-15,5 \times 0,4-0,6 \mathrm{~cm}$, retos, rostro $0,7-1,9 \mathrm{~cm}$ compr., margens onduladas, base aguda, valvas castanho-claras a vináceas, pubérulas; sementes 4-4,5 × 3-3,2 × 0,1-1,1 $\mathrm{mm}$, cilíndricas, testa coriácea, castanha a vinácea, hilo 1,5-2 mm compr., oblongo.

Endêmica do Brasil, ocorrendo nos estados da Bahia e Minas Gerais (Schultze-Kraft et al. 1990). C6, C7, D6, D7, E5, E6, E7, E9, F6, H7, I8 e J8: caatingas, campos rupestres e restingas, geralmente em afloramentos rochosos de granito ou arenito a 405-1480 m s.n.m. Floresce e frutifica durante o ano todo. A antese tem início em torno das 6:00 e as flores se mantêm abertas até cerca de 17:00.

Material selecionado - Abaíra, $13^{\circ} 23^{\prime} \mathrm{S}, 41^{\circ} 51^{\prime} \mathrm{W}, 1480 \mathrm{~m}$ s.n.m., 25 out. 1993 (fl.), W. Ganev 2327 (HUEFS, NY); Andaraí, $12^{\circ} 52^{\prime} \mathrm{S}, 41^{\circ} 18^{\prime} \mathrm{W}, 400 \mathrm{~m}$ s.n.m., 21 set. 2007 (fl., fr.), P.C. Natividade et al. 16 (HUEFS); Barra do Mendes, 12 $09^{\prime} 03^{\prime \prime S}$, 42 01 '03"W, 16 dez. 2009 (fl., fr.), E. Melo et al. 7642 (HUEFS); Campo Formoso, $10^{\circ} 22^{\prime} \mathrm{S}, 41^{\circ} 19^{\prime} \mathrm{W}, 14$ ago. 1999 (fl., fr.), E.M. Silva et al. 173 (HUEFS, IPA); Caravelas, $17^{\circ} 50^{\prime} 19^{\prime \prime} \mathrm{S}, 39^{\circ} 19^{\prime} 18^{\prime \prime} \mathrm{W}$, 27 ago. 2011 (fl., fr.), E.N. Matos et al. 462 (HUEFS); Guaratinga, $16^{\circ} 35^{\prime} 49^{\prime \prime S}, 39^{\circ} 54^{\prime} 50^{\prime \prime W}, 26$ ago. 2010 (fl., fr.), L. Daneu et al. 374 (CEPEC); Itaberaba, $12^{\circ} 24^{\prime} 44^{\prime \prime} \mathrm{S}, 40^{\circ} 32^{\prime} 12^{\prime \prime} \mathrm{W}$, ago. 2005 (fl.), L.P. Queiroz et al. 10783 (CEPEC, HUEFS); Itamaraju, fazenda Pau Brasil, 1659'26"S, 39³6'11"W, 11 fev. 2007 (fl.), A.M. Amorim et

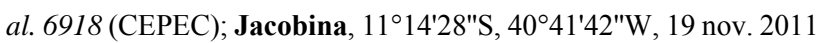
(fl.), N. Roque et al. 3455 (ALCB); Lençóis, 12²0'30"S, 41 $20^{\prime} 30^{\prime \prime} \mathrm{W}, 9$ mar. 2000 (fl., fr.), A.A. Ribeiro-Filho \& L.S. Funch 55 (HUEFS); Macarani, 1546'19"S, 40²4'50"W, 17 ago. 2001 (fl.), A.M. Carvalho et al. 7024 (ALCB, CEPEC); Miguel Calmon, $11^{\circ} 23^{\prime} \mathrm{S}, 40^{\circ} 45^{\prime} \mathrm{W}, 21$ ago. 1993 (fl., fr.), L.P. Queiroz et al. 3516

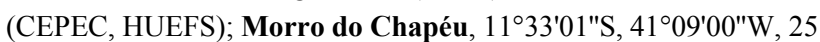
abr. 2010 (fl.), M.L. Guedes et al. 16987 (ALCB); Mucugê, $13^{\circ} 01^{\prime} 31^{\prime \prime S}, 41^{\circ} 21^{\prime} 52^{\prime \prime W}, 2$ nov. 2011 (f1.), I.M. Souza et al. s.n. (HUEFS 180189); Palmeiras, $12^{\circ} 34^{\prime} 00^{\prime \prime S}, 41^{\circ} 23^{\prime} 00^{\prime \prime} \mathrm{W}$, set. 2009 (fl.), M.S. Nunes 35 (HUEFS); Pindobaçu, 10³9'59"S, 40²1'59"W, 24 maio 2008 (fl.), L.A. Sousa \& R.B. Carvalho 112 (HUEFS); Porto Seguro, $16^{\circ} 52^{\prime}$ S, 3909'W, 12 dez. 1991 (fl.), H.P. Bautista \& M.C.

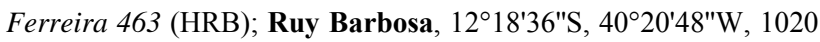
m s.n.m., 14 mar. 1999 (fl., fr.), F. França et al. 2669 (HUEFS); Salvador, $12^{\circ} 58^{\prime} \mathrm{S}, 38^{\circ} 30^{\prime} \mathrm{W}, 11$ jun. 2011 (fl.), M.L. Guedes et al. s.n. (ALCB 99560); Santa Cruz Cabrália, 16 ${ }^{\circ} 13^{\prime} 14 " \mathrm{~S}, 38^{\circ} 59^{\prime} 44^{\prime \prime} \mathrm{W}$, s.d. (fl.), J.G. Jardim et al. 2007 (CEPEC); Saúde, 1056'38"S, $40^{\circ} 24^{\prime} 30^{\prime \prime} \mathrm{W}, 542 \mathrm{~m}$ s.n.m., 25 jul. 2004 (fl., fr.), P. Fiaschi et al. 2407 (CEPEC, SPSF); Seabra, $12^{\circ} 25^{\prime} 07^{\prime \prime}$ S, 41 ${ }^{\circ} 46^{\prime} 13^{\prime \prime W}, 13$ out. 1981 (fl.), G. Hatschbach 44219 (CEPEC, MBM, RB); Senhor do Bonfim, $10^{\circ} 22^{\prime} 31^{\prime \prime S}, 40^{\circ} 12^{\prime} 28^{\prime \prime} \mathrm{W}, 12$ jul. 2005 (fl.), D. Cardoso 653 (HUEFS).

Centrosema coriaceum pode ser reconhecida pelos ramos lenhosos, folíolos coriáceos e ramos jovens, 
pecíolos, raque e folíolos glabros. Assemelha-se a $C$. arenarium pelos ramos lenhosos e folíolos coriáceos. Devido ao hábito e morfologia floral, também é confundida com Periandra mediterranea Mart. ex Benth., da qual se diferencia pelo calcar no estandarte (vs. calcar ausente em $P$. mediterranea) e pelo estigma truncado (vs. cuneiforme).

6. Centrosema macrocarpum Benth., Ann. Nat. Hist. 3(20): 436.1839.

Figuras 3J, 5A-C, H e 11.

Trepadeira volúvel, robusta, raramente arbusto, ca. $2 \mathrm{~m}$ alt.; ramos jovens, pecíolo e raque esparsamente pilosos. Estípulas 2,2-5,1 × 1-3 mm, oval-lanceoladas, acuminadas, face externa pilosa, caducas. Folhas 9,2 $17 \mathrm{~cm}$ compr., pinadas; pecíolo 1,8-5,3 cm compr.; raque $0,7-4 \mathrm{~cm}$ compr.; estipelas $4-6 \times 0,2-0,7 \mathrm{~mm}$, linear-triangulares, face externa esparsamente pilosa, geralmente caducas; folíolos 3, papiráceos a cartáceos, 4,5-9,5 × 2,9-6,2 cm, elípticos, ápice agudo ou mucronado, base obtusa, os laterais ligeiramente assimétricos, ambas as faces pilosas quando jovem tornando-se glabras com o desenvolvimento, venação reticulada, 6-11 pares de nervuras secundárias. Pseudorracemos 5,1-9 cm compr., mais curtos que a folha adjacente; brácteas e bractéolas esparsamente pilosas, brácteas de segunda ordem 5-9 × 3-5 mm, ovallanceoladas, bractéolas 10,1-16 × 4-6 mm, elípticooblongas, assimétricas; pedicelos $6-8,2 \mathrm{~cm}$ compr. Flores lilás, 2,9-3,5 cm compr.; cálice 1,1-1,2 cm compr., tubo $4-5 \times 5-8,5 \mathrm{~mm}$, face externa pilosa, face interna esparsamente pilosa, lacínias 4 , a superior 8 $12,5 \mathrm{~mm}$ compr., as laterais $4-9 \mathrm{~mm}$ compr., a inferior 4,2-8 mm compr., bífida; estandarte $2-3,3 \times 1,6-2,8$ $\mathrm{cm}$, orbicular, face externa pubescente, face interna glabrescente, calcar 1,3-3 mm compr.; alas falcadas, onduladas, 2,1-2,8 cm compr.; pétalas da carena 1,7-2,1 $\times 1,2-1,7 \mathrm{~cm}$, face externa pilosa, face interna esparsamente pilosa; androceu 3-3,2 cm compr., glabro, bainha estaminal $2,4-2,7 \mathrm{~cm}$ compr., filetes livres por 4-6 mm compr., anteras 1,2-1,5 × 1-1,2 mm, oblongoelípticas; pistilo 2,5-2,9 cm compr., ovário 1,3-1,6 $\times$ $0,1-0,2 \mathrm{~cm}$, séssil, piloso, estilete 1,2-1,3 cm compr., piloso, estigma truncado e ciliado. Legumes 15,5-22 $\times$ 5-8 cm, retos, rostro 1,2-1,8 cm compr., margens onduladas, base aguda, valvas castanho-claras com pontuações translúcidas, esparsamente pilosas; sementes $5-7,5 \times 4-4,1 \times 2,1-2,2 \mathrm{~mm}$, elípticas $\mathrm{e}$ curvadas, testa coriácea, castanho-escura, hilo ca. $3 \mathrm{~mm}$ compr., elipsoide.

Amplamente distribuída na região neotropical, desde o México até a Bolívia. No Brasil, ocorre da Região Norte até a Sudeste (Schultze-Kraft et al. 1990). E6, E7, F6 e F7: florestas estacionais semideciduais, até $1000 \mathrm{~m}$ s.n.m. Floresce entre maio e setembro e frutifica de agosto a setembro.

Material selecionado - Irajuba, $13^{\circ} 15^{\prime} \mathrm{S}, 40^{\circ} 00^{\prime} \mathrm{W}, 3$ set. 1981 (fl., fr.), L. Coradin 4799 (CEN, HUEFS, RB); Itaberaba, fazenda Serra da Monta, $12^{\circ} 31^{\prime} 40^{\prime \prime S}, 40^{\circ} 18^{\prime} 25^{\prime \prime} \mathrm{W}, 17$ jun. 1981 (fl.), B.B.
Celeste 154 (IBGE); Palmeiras, $1^{\circ} 28^{\prime} \mathrm{S}, 4^{\circ} 34^{\prime} \mathrm{W}, 22$ ago. 1981 (fl., fr.), L. Coradin et al. 4444 (RB); Rio de Contas, $13^{\circ} 06^{\prime} \mathrm{S}, 41^{\circ} 08^{\prime} \mathrm{W}$, 26 fev. 1989 (fl.), T.B. Cavalcanti 332 (NY).

Centrosema macrocarpum caracteriza-se pela presença de ramos lenhosos, folíolos elípticos, abaxialmente com nervuras proeminentes, e frutos compressos e grandes $(15,5-22 \times 5-8 \mathrm{~cm})$. É morfologicamente similar a $C$. pubescens, da qual se diferencia pelos frutos $(15,5-22 \mathrm{~cm}$ vs. 13,4-14 cm) e estipelas (4-6 $\mathrm{mm}$ vs. 1,5-3 $\mathrm{mm}$ ) maiores, além das pontuações translúcidas nas valvas dos frutos (vs. ausentes em C. pubescens). Além disso, $C$. macrocarpum apresenta hábito mais robusto, com ramos lenhosos (vs. ramos herbáceos em C. pubescens) e folíolos maiores e glabros em ambas as faces quando desenvolvidos (vs. folíolos pubescentes a tomentosos em ambas as faces).

7. Centrosema pascuorum Mart. ex Benth., Comm. Legum. Gen.: 56. 1837.

Figuras $1 \mathrm{G}, 3 \mathrm{~K}$ e 11.

Trepadeira ou erva, ca. $30 \mathrm{~cm}$ de alt.; ramos jovens, pecíolo, raque e eixo da inflorescência pilosos, tricomas setiformes esparsos. Estípulas 3-12 $~ 1-3 \mathrm{~mm}$, triangulares, acuminadas, face externa pilosa a glabrescente, caducas. Folhas 7,5-19,5 cm compr., pinadas; pecíolo $1-6 \mathrm{~cm}$ compr.; raque $0,5-2,4 \mathrm{~cm}$ compr.; estipelas 3-9 × 0,1-0,8 mm, linear-triangulares, rígidas, face externa esparsamente pilosa, persistentes; folíolos 3, cartáceos, 4,7-13,4 × 0,2-1,5 cm, lineares, oval-lanceolados, ápice agudo, raramente mucronado, base acuminada, os laterais ligeiramente assimétricos, raramente oblongos, face adaxial esparsamente pilosa, face abaxial pilosa a pubescente, principalmente ao longo das nervuras, venação reticulada, $8-18$ pares de nervuras secundárias. Pseudorracemos 1,2-5,1 cm compr., 1(2) flores, mais curtos que a folha adjacente; brácteas e bractéolas pilosas a pubérulas, brácteas de segunda ordem 1-5 × 1-3,1 mm, ovais, margens ciliadas, bractéolas 4-9 × 1,8-4,2 mm, elípticooblongas, assimétricas; pedicelos 0,9-4 cm compr. Flores lilás, 1-3,2 cm compr.; cálice 6-11 mm compr., tubo 2-4 × 1,8-5 mm, face externa esparsamente pilosa, face interna pilosa a glabrescente, lacínias 4 , a superior 3-8 mm compr., as laterais 4-8 mm compr., a inferior 3-8 mm compr., bífida; estandarte 1,2-2,5 × 1-2,2 cm, suborbicular, face externa pubescente, face interna glabrescente, calcar 0,9-2 $\mathrm{mm}$ compr.; alas falcadas, onduladas 5,5-13,5 mm compr.; pétalas da carena $0,5-$ $1,5 \times 0,3-1 \mathrm{~cm}$, face externa pilosa, face interna esparsamente pilosa; androceu 0,5-2,8 cm compr., glabrescente, bainha estaminal $0,3-1,5 \mathrm{~cm}$ compr., filetes livres por 2-6 mm compr., anteras $0,4-1 \times 0,3-$ $1,2 \mathrm{~mm}$, oblongo-elípticas; pistilo 0,8-3,2 cm compr., ovário 6-17 × 0,2-0,9 mm, séssil, pubescente, tricomas adpressos, estilete $2-15 \mathrm{~mm}$ compr., pubérulo, estigma truncado e ciliado. Legumes $6,3-8,5 \times 0,3-0,6 \mathrm{~cm}$, retos, rostro $0,6-1 \mathrm{~cm}$ compr., margens retas a levemente onduladas, base aguda, valvas castanho- 
escuras, pilosas, tricomas esparsos; sementes 3-4,1 $\times 2$ 2,5 $\times 0,7-1,5 \mathrm{~mm}$, oblongas, testa coriácea, castanhoclara, hilo 0,9-1,2 mm compr., oblongo.

Ocorre do México a América do Sul tropical, incluindo a costa do Equador, Guiana, norte da Venezuela, além do Pantanal e da Região Nordeste do Brasil (Schultze-Kraft et al. 1990). B6/7, C4, D7, E3, E4 e F6: caatingas e cerrados, principalmente em áreas com secas prolongadas (Queiroz 2009), em solos arenosos. Floresce e frutifica entre fevereiro e agosto. A antese tem início em torno das 6:00 e as flores se mantêm abertas até aproximadamente às 17:00.

Material selecionado - Brumado $13^{\circ} 38^{\prime} \mathrm{S}, 41^{\circ} 51^{\prime} \mathrm{W}, 28$ mar 1991 (fl.), G.P. Lewis \& S.M.M. Andrade 1925 (CEPEC); Buritirama, $10^{\circ} 42^{\prime} 29^{\prime \prime} \mathrm{S}, 4^{\circ} 37^{\prime} 49^{\prime \prime} \mathrm{W}$, K.L. Barreto et al. 48 (HUEFS); Casa Nova, arredores da represa de Sobradinho, 0909'43"S, 4058'14"W, 5 jul. 2009 (bot., fl.), J.P. Souza 9841 (HST); Cocos, 1243'01"S, 44³3'59"W, 530 m s.n.m., 17 mar. 1972 (bot., fl.), W.R. Anderson 37103 (UB); Ibotirama, 12¹0'S, $43^{\circ} 12^{\prime} \mathrm{W}, 410$ m s.n.m., 25 mar. 1984 (fl., fr.), O.A. Salgado \& H.P. Bautista 294 (CEPEC, HRB, RB); Juazeiro, campus da Univasf, 367 m s.n.m, 09²6'52.4"S, 40³1'34.2"W, 19 abr. 2007 (fl., fr.), O.C.M. Vasconcelos 1658 (HUEFS); Serrolândia, $11^{\circ} 18^{\prime} 22^{\prime \prime S}, 40^{\circ} 16^{\prime} 18^{\prime \prime} \mathrm{W}, 29$ mar. 1982 (fl.), W.N. Fonseca 257 (HRB, RB).

Centrosema pascuorum pode ser reconhecida pelos folíolos lineares a lanceolados, inflorescências menores que as folhas adjacentes, flores relativamente pequenas $(<3,2 \mathrm{~cm}$ compr.) e lacínias do cálice alongadas, com comprimentos diferentes, porém maiores que as bractéolas. É morfologicamente semelhante a $C$. brasilianum var. angustifolium e $C$. virginianum, das quais se distingue pelo tamanho da flor e comprimento desigual das lacínias do cálice.

8. Centrosema plumieri (Turpin ex Pers.) Benth., Comm. Legum. Gen.: 54. 1837.

Figuras 2A, B, 3L, 5D-G e 12.

Trepadeira volúvel ou arbusto escandente, ca. $3 \mathrm{~m}$ alt.; ramos jovens, pecíolo e raque esparsamente pilosos. Estípulas 4-13 $\times 1,5-5 \mathrm{~mm}$, ovaltriangulares, acuminadas, face externa glabrescente, persistentes. Folhas 10,5-24(-28) cm compr., pinadas; pecíolo 1,5-11,5 cm compr.; raque 1,2-3,5 cm compr.; estipelas 5-14 × 0,5-2 mm, setiforme-triangulares, face externa glabrescente, geralmente caducas; folíolos 3, membranáceos a cartáceos, 4,4-15,5 × 3,4-11,1 cm, o terminal geralmente rômbico, mais largos na base, ápice acuminado, base obtusa, os laterais ovais, face adaxial pilosa a glabrescente, face abaxial pilosa, tricomas sinuosos e adpressos, reticulada, 5-10 pares de nervuras secundárias. Pseudorracemos 3-11,5 cm compr., mais curtos que a folha adjacente; brácteas e bractéolas glabras, brácteas de segunda ordem 4-5 $\times$ 2,2-5 mm, oval-côncavas, bractéolas 1,5-2,9 × 0,6-1,5 $\mathrm{cm}$, elíptico-oblongas, assimétricas; pedicelos 0,3-1 $\mathrm{cm}$ compr. Flores brancas, com guia de néctar vináceo na face superior do estandarte, $3-5 \mathrm{~cm}$ compr.; cálice 5,3-9,5 mm compr., tubo 4,5-7 × 6-10,3 mm, face externa pilosa, ciliada nas extremidades, face interna glabrescente, lacínias 4 , a superior 2-5 $\mathrm{mm}$ compr., as laterais 2-3 mm compr., a inferior 1-2 mm compr., bífida; estandarte 2,8-4,3 × 1,6-4,2 cm, orbicular, face externa pubescente, tricomas adpressos, face interna pilosa a glabrescente, calcar 1-3 mm compr.; alas falcadas, onduladas 2,7-4 cm compr.; pétalas da carena $2-3,3 \times 1,2-2 \mathrm{~cm}$, face externa pilosa, face interna glabrescente; androceu 3,4-5 cm compr., glabrescente, bainha estaminal 2,6-4,1 cm compr., filetes livres por 7-10 mm compr., anteras $1-2 \times 1-1,5$ $\mathrm{mm}$, oblongo-elípticas; pistilo $2,7-5 \mathrm{~cm}$ compr., ovário 10-23 × 1-2 mm, séssil, pubescente, estilete 1,7-2,7 cm compr., pubérulo, estigma truncado e ciliado. Legumes 8,5-22,7 × 7-19 cm, retos, rostro 0,5-3 cm compr., margens onduladas, base aguda, valvas castanho-escuras, esparsamente pilosas, tricomas adpressos; sementes 6-9 × 5,5-7 × 2,3-5 mm, orbiculares ou ovais, testa coriácea, castanho-escura a vinácea, hilo 4,5-6 mm compr., oblongo.

Amplamente distribuída na região neotropical, ocorrendo também como planta introduzida na África. Pode ser encontrada em todas as Regiões do Brasil (Schultze-Kraft et al. 1990). D6, D7 e G8: florestas ombrófilas e estacionais semideciduais, de 300 a 900 m s.n.m. Floresce e frutifica entre maio e outubro.

Material selecionado - Ilhéus, Área do CEPEC, Km 22 da rodovia Ilhéus-Itabuna (BR-415), CEPLAC, quadra H, 14²4'20"S, 3902'56"W, 6 set. 1983 (fl., fr.), E.B. Santos \& L.A.S. Barreto 63 (CEPEC, HUEFS); Irecê, fazenda Ipê, $11^{\circ} 18^{\prime} 01^{\prime \prime S}, 41^{\circ} 52^{\prime} 00^{\prime \prime} \mathrm{W}, 11$ abr. 2001 (fr.), T.S Nunes et al. 318 (HUEFS); Jacobina, 11 16'19"S, $40^{\circ} 27^{\prime} 48^{\prime \prime} \mathrm{W}, 25$ ago. 1980 (fl., fr.), R.P. Orlandi 240 (CEPEC, HRB, RB, UB); Ubaitaba, $14^{\circ} 18^{\prime} 01^{\prime \prime S}, 39^{\circ} 19^{\prime} 59^{\prime \prime} \mathrm{W}, 12$ out. 1998 (fl.), G. Hatschbach \& J.M. Silva 68454 (CEPEC, MBM); Uruçuca, 14³5'36"S, 39²17'03"W, 1 jul. 1965 (fl.), R.P. Belém et al. 1264 (UB).

Centrosema plumieri caracteriza-se pos folíolos ovais a rômbicos, mais largos na base, sendo o terminal geralmente rômbico e os laterais ovais, inflorescências com pedúnculo menor que o pedicelo, flores grandes (3-5 cm compr.), pétalas brancas com guia de néctar esbranquiçado e frutos compressos e longos (8,5-22,7 cm compr.). Quando herborizada, é facilmente reconhecida pela coloração enegrecida.

9. Centrosema pubescens Benth., Comm. Legum. Gen.: 55. 1837.

Figuras $1 \mathrm{H}, 3 \mathrm{M}$ e 12.

Trepadeira volúvel ca. 1-2,5 m alt.; ramos jovens, pecíolo e raque pubescentes a tomentosos, tricomas sinuosos. Estípulas $2-7 \times 0,8-1,5 \mathrm{~mm}$, ovaltriangulares, acuminadas, face externa pilosa, persistentes. Folhas 6,7-12 cm compr., pinadas; pecíolo 0,8-4,2(-5,1) cm compr.; raque 0,5-2,2 cm compr.; estipelas 1,5-3 × 0,1-0,2 mm, linear-triangulares, face externa pilosa, persistentes; folíolos 3 , membranáceos a papiráceos, (3,9-)5-9,8 × 2-6,2 cm, oval-elípticos ou lanceolados, ápice acuminado, geralmente agudo, base obtusa, os laterais ligeiramente assimétricos, face 


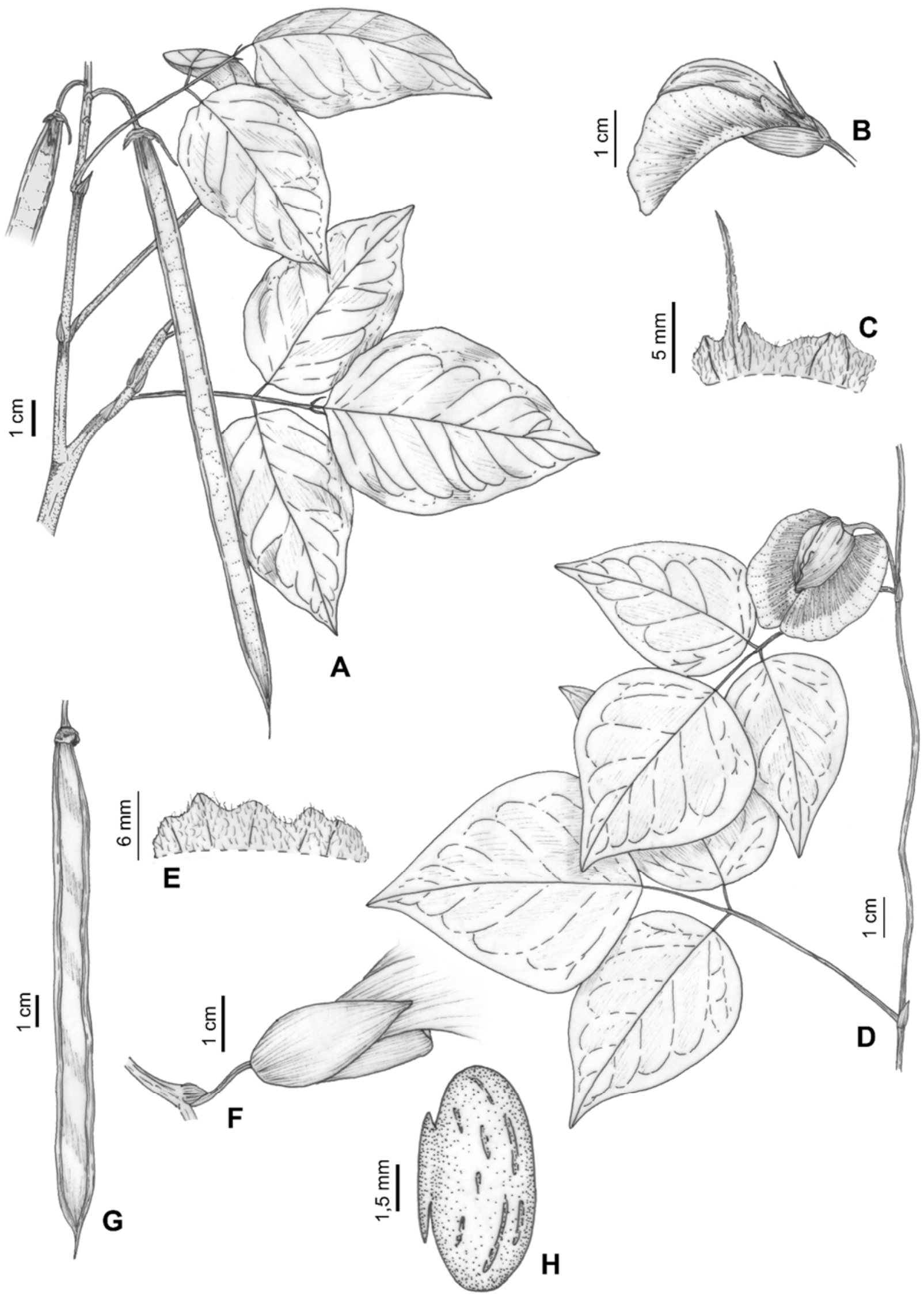

Figura 5. A-C. Centrosema macrocarpum: A- ramo com frutos; B- flor em vista lateral; C- cálice. D-G. C. plumieri: D- ramo com flor; E- cálice; F- bractéola em vista lateral; G- fruto. H. C. macrocarpum: semente. (Desenhado por Lucas C. Marinho: A- Coradin 5010; B- Coradin 5061; C e H- Coradin et al. 4799; D- Coradin et al. 2844; E-G- Oliveira 1111). 
adaxial pilosa, tricomas sinuosos, face abaxial pubescente, venação reticulada, 6-10 pares de nervuras secundárias. Pseudorracemos 4-9,5 cm compr., mais longos que a folha adjacente; brácteas e bractéolas pilosas, com tricomas setiformes, brácteas de segunda ordem 5,5-9 × 2-4 mm, oval-lanceoladas, bractéolas 7,5-13 × 3,5-7 mm, elíptico-oblongas, assimétricas; pedicelos 0,6-1,1 cm compr. Flores lilás, 2,6-4,9 cm compr.; cálice 7,5-12 mm compr., tubo 4-5 × 5-8 mm, face externa pilosa, face interna glabrescente, lacínias 4 , a superior 3-8,5 $\mathrm{mm}$ compr., as laterais 2-4 $\mathrm{mm}$ compr., a inferior 1-3 mm compr., bífida; estandarte 2,4-4,3 $\times$ 2,4-3,8 $(-4,6) \mathrm{cm}$, orbicular, face externa pubescente, face interna glabrescente, calcar 1-2,5 mm compr.; alas falcadas, onduladas 1,8-2,7 cm compr.; pétalas da carena $1,7-2,4 \times 0,9-1,4 \mathrm{~cm}$, face externa pilosa, face interna pilosa a glabrescente; androceu $1,8-3,8 \mathrm{~cm}$ compr., glabrescente, bainha estaminal (1,3-)1,9-3,2 cm compr., filetes livres por 5-7 mm compr., anteras 1$1,3 \times 0,8-1,4 \mathrm{~mm}$, oblongas; pistilo 1,8-3 cm compr., ovário 9-16(-23) × 0,5-1 mm, séssil, piloso, tricomas adpressos, estilete 0,9-1,3(-1,8) cm compr., piloso, estigma truncado e ciliado. Legumes 13,4-14 × 0,4-0,5 $\mathrm{cm}$, retos ou falcados, rostro $0,7-1,7 \mathrm{~cm}$ compr., margens onduladas, base aguda, valvas castanhas a vináceas, esparsamente pilosas; sementes 4,5-5 × 2,8-3 $\times$ 1,8-2,2 mm, oblongas, testa coriácea, castanha a vinácea, hilo 2-2,5 mm compr., elipsoide.

Amplamente distribuída na região neotropical, ocorrendo do sudeste dos EUA até o sul do Brasil, e também como espécie introduzida na África e na Ásia (Schultze-Kraft et al. 1990; Duno de Stefano et al. 2008). No Brasil, ocorre em todas as Regiões (Souza 2019). D9, E6, E9, F5, F8, G5, G8, H7, H8, H9 е J8: florestas ombrófilas, restingas, caatingas e áreas antropizadas. Floresce e frutifica durante o ano todo. A antese tem início aproximadamente às 6:00 e as flores se mantêm abertas até às 17:00.

Material selecionado - Aurelino Leal, Povoado da Pedra Grande, $14^{\circ} 18^{\prime} 00^{\prime \prime}$ S, 39¹9'37"W, 16 jul. 1980 (fl., fr.), L. Coradin et al. 2939 (HUEFS, NY); Belmonte, Estação Experimental Gregório Bondar, 1551'48"S, 38 52'58"W, 30 mar. 1982 (fl.), H.S. Brito \& S.G. Vinha 161 (CEPEC); Caetité, Distrito de Brejinho das Ametistas, $14^{\circ} 16^{\prime} 00^{\prime \prime S}, 42^{\circ} 31^{\prime} 34^{\prime \prime} \mathrm{W}, 10$ jan. 2006 (fl., fr.), A.K.A Santos et al. 559 (HUEFS); Cachoeira, $13^{\circ} 45^{\prime} \mathrm{S}, 39^{\circ} 30^{\prime} \mathrm{W}$, jun. 1980 (fl.), Grupo Pedra do Cavalo 198 (ALCB); Itambé, 15²15'S, 40³7'W, abr. 1971 (fl.), G.C.P. Pinto s.n. (ALCB 1633); Lençóis,

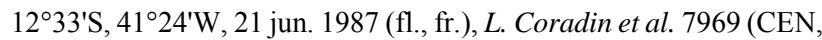
HUEFS, RB); Macaúbas, $13^{\circ} 01^{\prime} \mathrm{S}, 42^{\circ} 42^{\prime} \mathrm{W}, 16$ jun. 2004 (fl.), G. Hatschbach et al. 77934 (MBM); Nova Viçosa, 17²53'32"S, 39²2'18"W, 20 out. 1983 (fl.), G. Hatschbach 47037 (CEPEC, MBM); Salvador, Campus Universitário de Ondina (Instituto de Biologia), 1258'15"S, 38³0'39"W, 5 out. 1987 (fl.), S. Selma s.n. (ALCB 19895); Tucano, $11^{\circ} 07^{\prime 2} 24^{\prime \prime S}, 38^{\circ} 46^{\prime} 25^{\prime \prime} \mathrm{W}, 4$ jan. 2006 (fl., fr.), D. Cardoso \& A. Amadeu 896 (HUEFS); Una, fazenda Cascata, 1517'36"S, 3904'31"W, 5 maio 1983 (fl.), J.L. Hage et al. 1683 (CEPEC, RB).

Centrosema pubescens pode ser reconhecida pelos ramos jovens, pecíolo e raque foliar pubescentes a tomentosos e pelos folíolos com face abaxial pubescente. A forma dos folíolos é semelhante àquela de C. brasilianum, da qual se diferencia por apresentar os ramos, pecíolo e raque foliar pubescentes (vs. glabros em C. brasilianum), ambas as faces dos folíolos pilosas a pubescentes (vs. esparsamente pilosas) e cálice com lacínia carenal longa e curva (vs. curta e linear).

10. Centrosema rotundifolium Mart. ex Benth., Comm. Legum. Gen.: 55. 1837.

Figuras 2C, 3N-P, 6F, G e 13.

Trepadeira volúvel ou prostrada; ramos jovens, pecíolo e raque pubescentes a tomentosos, tricomas longos e setiformes. Estípulas 2-4 × 1-2,5 mm, ovaltriangulares, acuminadas, face externa pilosa, persistentes. Folhas 3,8-10,4 cm compr., pinadas; pecíolo 1-5,8 cm compr.; raque 3-14 cm compr.; estipelas 2-5 $\times$ 0,5-2 $\mathrm{mm}$, lineares, face externa esparsamente pilosa, persistentes; folíolos 3-5, cartáceos, 8-37 × 6-32 cm, orbiculares a obovais, ou elípticos, ápice arredondado a truncado, base obtusa, os laterais ligeiramente assimétricos, face adaxial tomentosa, face abaxial pubescente, venação reticulada, 4-6 pares de nervuras secundárias. Pseudorracemos 2,5-5,5 cm compr., mais curtos que a folha adjacente; brácteas e bractéolas esparsamente pilosas, brácteas de segunda ordem 1-6×1-3 mm, ovais, bractéolas 7-11× 2,5-6 mm, elíptico-oblongas, assimétricas; pedicelos 0,9-2,8 cm compr. Flores lilás, 2,4-6 cm compr.; cálice 8-13 mm compr., tubo 3-5 × 3-7 mm, face externa pilosa, tricomas longos e eretos, face interna pilosa a glabrescente, lacínias 4, a superior 7-10 mm compr., as laterais $3-5 \mathrm{~mm}$ compr., a inferior $2-5 \mathrm{~mm}$ compr., bífida; estandarte 1,6-2,7 × 2-3,4 cm, orbicular, face externa pubescente, face interna glabra, calcar 1,3-2,5 $\mathrm{mm}$ compr.; alas falcadas, onduladas $1,5-2,7 \mathrm{~cm}$ compr.; pétalas da carena 1,4-2,6 ×0,8-1,4 cm, face externa pilosa, face abaxial esparsamente pilosa; androceu 2,1-2,6 cm compr., glabrescente, bainha estaminal 1,6-2,1 cm compr., filetes por livres por 2-5 $\mathrm{mm}$ compr., anteras 0,9-1,5 × 0,8-1 mm, oblongoelípticas; pistilo 7,8-10,7 mm compr., ovário 7-9 × 0,8$1,5 \mathrm{~mm}$, séssil, pubescente, estilete $0,8-1,7 \mathrm{~cm}$ compr., piloso a pubescente, estigma truncado e ciliado. Legumes $2,8-4 \times 0,4-1 \mathrm{~cm}$, falcados, oblongos, rostro ca. 0,4 cm compr., margens retas, base aguda; valvas castanho-claras, pubescentes; [sementes não vistas].

Endêmica do Brasil, ocorrendo nas Regiões Nordeste e Sudeste (Minas Gerais) (Schultze-Kraft et al. 1990). B5, D2, D6, E6 e G4: caatingas e florestas estacionais deciduais. Floresce e frutifica entre fevereiro e julho.

Material selecionado - Carinhanha, Médio São Francisco, a 1

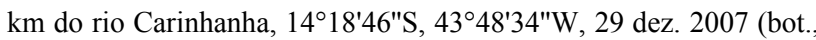
fl.), M.L. Guedes \& F.S. Gomes 14111 (HUEFS); Formosa do Rio Preto, à beira do Rio Preto, $11^{\circ} 02^{\prime} 54^{\prime \prime} \mathrm{S}, 45^{\circ} 11^{\prime} 34^{\prime \prime} \mathrm{W}, 31$ mar. 2000 (fr.), R.M. Harley et al. 53778 (HUEFS); Morro do Chapéu, fazenda São João dos Brejões, $11^{\circ} 15^{\prime} 29^{\prime \prime S}, 41^{\circ} 05^{\prime} 42^{\prime \prime W}, 14$ abr. 2007 (fl.), E. Melo et al. 4717 (HUEFS); Pilão Arcado, 1 km depois da ponte sobre 
o Riacho de Lage, $30 \mathrm{~km}$ de Remanso na estrada para Pilão Arcado, 0945'32"S, 42¹7'53"W, 28 abr. 2001 (fl., fr.), L.P. Queiroz 6609 (HUEFS); Utinga, $12^{\circ} 31^{\prime} \mathrm{S}, 41^{\circ} 14^{\prime} \mathrm{W}, 1$ jan. 1839 (fl., fr.), J.S. Blanchet 2705 (HUEFS).

Centrosema rotundifolium pode ser reconhecida pelo hábito prostrado, ramos tomentosos, folhas 3- ou 5folioladas, folíolos orbiculares a obovais ou elípticos, com ápice arredondado a truncado, sendo os basais levemente mais longos do que o terminal, e frutos falcados e pequenos (2,8-4 cm compr.). BarbosaFevereiro (1977) tratou C. heptaphyllum como sinônimo de C. rotundifolium; entretanto, Williams \& Clements (1990) consideraram-nas espécies distintas. Neste trabalho, seguimos Barbosa-Fevereiro (1977), e consideramos $C$. heptaphyllum sinônimo de $C$. rotundifolium.

\section{Centrosema sagittatum (Humb. \& Bonpl. ex Willd.)} Brandegee, Zoë 5(10B): 202. 1905.

Figuras 3Q, 6C-E e 13.

Trepadeira volúvel; ramos jovens, pecíolo e raque, esparsamente pilosos. Estípulas 3-9 × 0,8-3,5 mm, triangular-lanceoladas, acuminadas, glabrescentes, persistentes. Folhas 6,9-24,2 cm compr., pinadas; pecíolo alado $2-7(-10,1) \mathrm{cm}$ compr.; raque ausente; estipelas $2-6 \times 0,1-0,5 \mathrm{~mm}$, setiforme-triangulares, face externa esparsamente pilosa, caducas; folíolo 1 , membranáceo a cartáceo, 6-21 × 4-11(-12,5) cm, sagitado, ápice acuminado, base sagitada, face adaxial pilosa a glabrescente, tricomas sinuosos e adpressos, face abaxial esparsamente pilosa, principalmente ao longo das nervuras, venação reticulada, 4-8 pares de nervuras secundárias. Pseudorracemos 3,5-7 cm compr., mais curtos que a folha adjacente; brácteas e bractéolas glabrescentes, brácteas de segunda ordem 1,5-6 × 2-5 mm, oval-lanceoladas, bractéolas 4,5-10 $\times 2-5 \mathrm{~mm}$, elíptico-oblongas, assimétricas; pedicelos 0,5-0,9 mm compr. Flores brancas $2,2-4,8 \mathrm{~cm}$ compr.; cálice 7-13,5 mm compr., tubo 5-7 × 5-8 $\mathrm{mm}$, face externa pilosa, face interna esparsamente pilosa, lacínias 4 , a superior 3-7 mm compr., as laterais 2-4,2 mm compr., a inferior 1,8-2 mm compr., bífida, unida a mais da metade da base; estandarte 2,1-5,8 $\times 1,7-3,2$ $\mathrm{cm}$, orbicular, face externa pubescente, face interna glabrescente, calcar 1,2-3 mm compr.; alas falcadas, onduladas 2-2,4 cm compr.; pétalas da carena 1,9-2,3 $\times 1-1,6 \mathrm{~cm}$, face externa pilosa, face interna glabrescente; androceu 2,3-3,3 cm compr., glabrescente, bainha estaminal 1,7-2,4 cm compr., filetes livres por 5-6 mm compr., anteras $1-1,5 \times 1-1,3$ $\mathrm{mm}$, oblongo-elípticas; pistilo 2,3-3,1 cm compr., ovário $11-17 \times 0,7-1 \mathrm{~mm}$, séssil, pubescente, estilete 1,2-1,4 cm compr., pubérulo, estigma truncado e ciliado. Legumes $14-19 \times 6-8 \mathrm{~cm}$, retos, rostro ca. $1 \mathrm{~cm}$ compr., margens onduladas, base aguda, valvas castanho-claras, esparsamente pilosas; sementes 5,5-7 $\times$ 3,5-5 × 1,7-3,1 mm, oblongas, testa coriácea, castanho-enegrecida a vinácea, hilo 2,5-2,7 mm compr., oblongo.
Ocorre do México ao Paraguai, atingindo o nordeste da Argentina (Schultze-Kraft et al. 1990). No Brasil, é registrada nas Regiões Nordeste, Centro-Oeste, Sudeste e Sul (Paraná) (Souza 2019). C7, D7, E6, E7, E8, F4, F5, G7, G8 e H7: florestas estacionais semideciduais, florestas ombrófilas e estacionais e restinga. Floresce em maio e junho; encontrada com frutos em maio, junho, setembro e dezembro.

Material selecionado - Encruzilhada, margem do rio Prado, 15³1'48"S, 4054'36"W, 23 maio 1968 (fl.), R.P. Belém 3593 (NY); Feira de Santana, Distrito de São José da Itapororoca, $12^{\circ} 38^{\prime} \mathrm{S}$, $39^{\circ} 28^{\prime} \mathrm{W}, 18$ jun. 1985 (fr.), H.P. Bautista et al. 1031 (HRB); Ilhéus, 1447'21"S, 41³9'00"W, 6 abr.1992 (fr.), G. Hatschbach et al. 56935 (MBM); Macaúbas, arredores da Lagoa do Maurício, 1301'11"S, 42 $41^{\prime} 55^{\prime \prime}$ W, 15 jun. 2004 (fl., fr.), G. Hatschbach et al. 77880

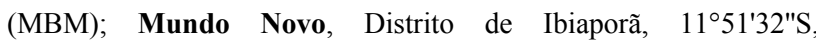
40²8'20"W, ago. 1972 (fl.), G.C.P. Pinto s.n. (ALCB 1629); Paramirim, $13^{\circ} 17^{\prime} 47^{\prime \prime} \mathrm{S}, 42^{\circ} 14^{\prime} 50^{\prime \prime} \mathrm{W}, 29$ abr. 2007 (fl.), A.A. Conceição et al. 1970 (ALCB, HUEFS); Rio de Contas, Distrito de Marcolino Moura, $14^{\circ} 16^{\prime} 00^{\prime \prime} \mathrm{S}, 39^{\circ} 00^{\prime} 59^{\prime \prime} \mathrm{W}, 30$ jun. 2007 (fr.), $D$. Cardoso \& E.A. Correia 2087 (HUEFS); Ruy Barbosa, 12 ${ }^{\circ} 19^{\prime} 39^{\prime \prime S}$, 40²8'33"W, 3 set. 2004 (fr.), L.P. Queiroz et al. 9441 (HUEFS); Senhor do Bonfim, fazenda Passaginha, $10^{\circ} 22^{\prime} 43^{\prime \prime S}, 40^{\circ} 12^{\prime} 22^{\prime \prime} \mathrm{W}$, 600-700 m s.n.m., 14 jul. 2005 (fl.), D. Cardoso et al. 742 (HUEFS);

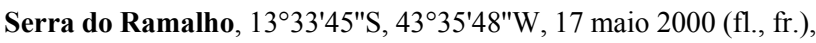
G. Hatschbach et al. 71260 (MBM); Vitória da Conquista, fazenda Santa Maria, $14^{\circ} 51^{\prime} 58^{\prime \prime} \mathrm{S}, 40^{\circ} 50^{\prime} 21^{\prime \prime W}, 19$ fev.1992 (fl.), A.M.V. Carvalho 3811 (CEPEC, NY, RB).

Centrosema sagittatum se diferencia das demais espécies da Bahia pelas folhas unifolioladas, com folíolo sagitado, pecíolo alado e sem raque foliar, e flores com pétalas brancas e manchas violáceas.

12. Centrosema schottii (Millsp.) K.Schum., Just's Bot. Jahresber. 26(1): 353. 1900.

Figuras 2D, 3R, 6A, B e 14.

Trepadeira volúvel, 1-2 $\mathrm{m}$ alt.; ramos jovens, pecíolo e raque pilosos a glabrescentes. Estípulas 3,5$10 \times 1,5-4 \mathrm{~mm}$, oval-triangulares, acuminadas, face externa pilosa, persistentes. Folhas 5,2-27 cm compr., pinadas; pecíolo 1,2-11 cm compr.; raque 0,9-4,2 cm compr.; estipelas 3,5-7,5 $\times 0,1-0,5 \mathrm{~mm}$, setiformetriangulares, face externa esparsamente pilosa, caducas; folíolos 3, membranáceos, 2,8-10,7 × 1-9,5 cm, triangulares, ápice acuminado, base hastada, os laterais ligeiramente assimétricos, face adaxial pilosa, tricomas sinuosos nas extremidades, face abaxial pilosa, tricomas sinuosos, adpressos e pegajosos, venação reticulada, 58 pares de nervuras secundárias. Pseudorracemos 5,2$12 \mathrm{~cm}$ compr., mais curtos que a folha adjacente; brácteas e bractéolas esparsamente pilosas, brácteas de segunda ordem 5-7,2 × 2-7 mm, ovais a largamente elípticas, bractéolas $1,5-2 \times 0,3-1,2 \mathrm{~cm}$, elípticooblongas, assimétricas; pedicelos 0,4-1 cm compr. Flores lilás, 2,7-5,2 cm compr.; cálice 4,5-6 $\mathrm{mm}$ compr., tubo 3-3,5 × 6-7 mm, face externa pilosa, face interna esparsamente pilosa, lacínias 4 , a superior 2,5-3 $\mathrm{mm}$ compr., as laterais 1,3-2 mm compr., a inferior 1,5-4 mm compr., aguda a ondulada estandarte orbicular 


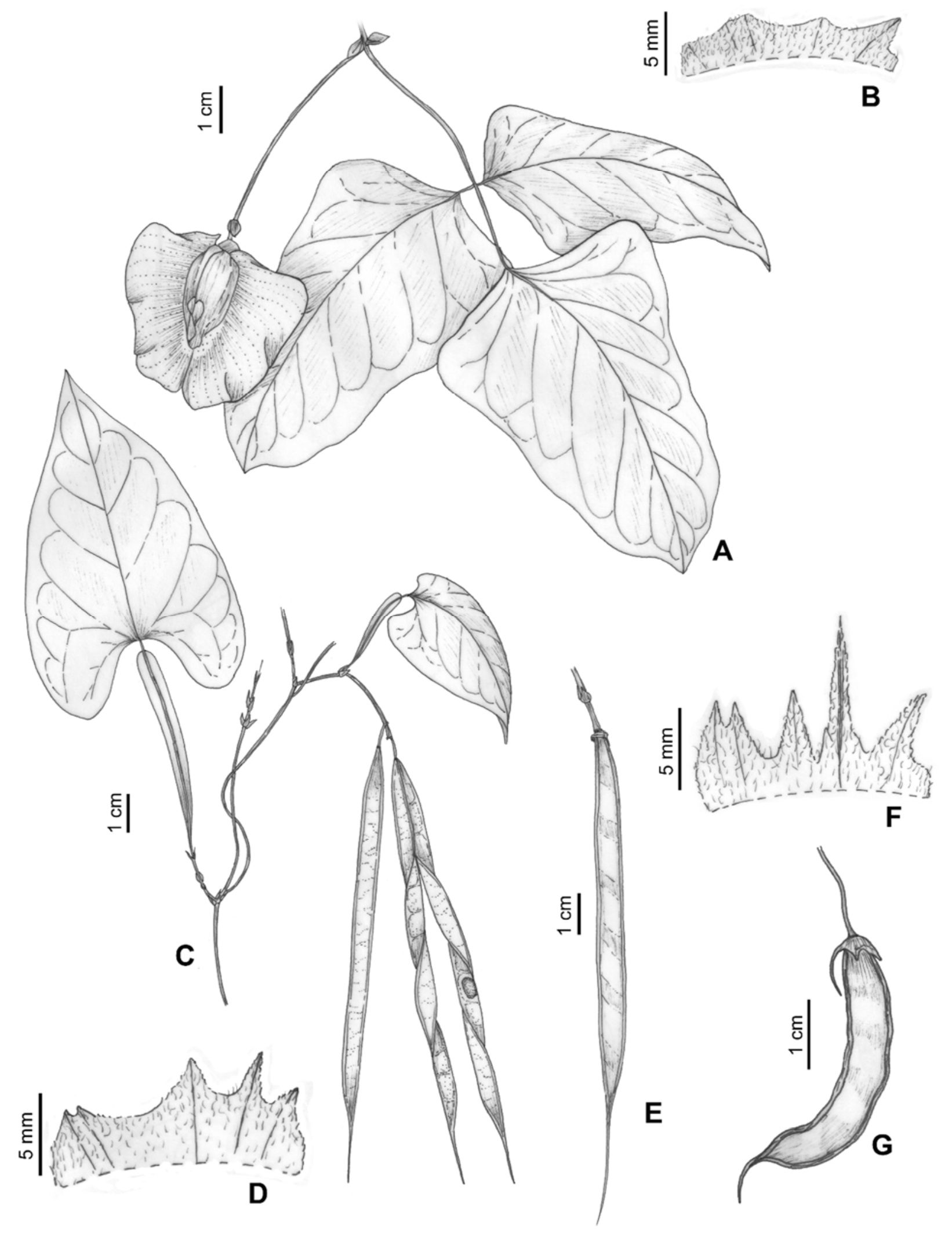

Figura 6. A, B. Centrosema schottii: A- ramo com folha e inflorescência; B- cálice. C-E. C. sagittatum: C- ramo com folha e fruto; D- cálice; E- fruto. F, G. C. rotundifolium: F- cálice; G-fruto (Desenhado por Lucas C. Marinho: A e D- Fotius 4028; C- Queiroz 10013; E- Fernandes s.n. EAC 3286). 
$2,2-3,5 \times 2,2-4,2 \mathrm{~cm}$, face externa pilosa a pubescente, face interna glabrescente, calcar 1-3,5 mm compr.; alas falcadas, onduladas 2,6-4 cm compr.; pétalas da carena 2,1-3 × 1,4-1,8 $\mathrm{mm}$, face externa pilosa, face interna esparsamente pilosa; androceu 3,8-4,2 cm compr., glabro, bainha estaminal 3,1-3,2 cm compr., filetes livres por 6-10 mm compr., anteras 1,3-2 × 0,8-1 mm, oblongo-elípticas; pistilo 3,1-4,1 cm compr., ovário 10 $18 \times 0,8-2 \mathrm{~mm}$, séssil, tricomas adpressos, estilete $2,1-$ $2,3 \mathrm{~cm}$ compr., piloso, estigma truncado e ciliado. Legumes 8,5-13,5 × 6-9 $\mathrm{cm}$, retos a falcados, rostro 1,6-3,5 cm compr., margens onduladas, base aguda, valvas castanho-claras, esparsamente pilosas, tricomas adpressos; sementes 5-6 × 4-5 × 3,4-3,5 mm, oblongas, testa coriácea, castanha, hilo $2-2,9 \mathrm{~mm}$ compr., oblongo a elíptico.

Ocorre no México, Guatemala, norte da Venezuela, Equador, Argentina e Brasil, neste último, nas Regiões Nordeste e Centro-Oeste (Schultze-Kraft et al. 1990; Duno de Stefano et al. 2008). B7, D6, D7 e E6: caatingas, geralmente em solos próximos a afloramentos calcários. Floração de maio a outubro e frutificação de abril a agosto. A antese tem início aproximadamente às 6:00 e as flores se mantêm abertas até às 17:00.

Material selecionado - Juazeiro, $09^{\circ} 48,33^{\prime} \mathrm{S}, 40^{\circ} 38,33^{\prime} \mathrm{W}, 28$ maio 1985 (fl., fr.), G. Fotius 4028 (HST); Irecê, 11¹8'16"S,

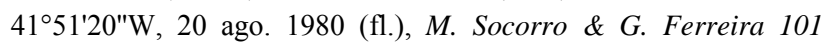
(IBGE); Morro do Chapéu, 11³3'28.7"S, 4054'21.4"W, 15 jul. 2013 (fl., fr.), K.L. Barreto et al. 84 (HUEFS); Nova Redenção, Povoado de Queimadas, $12^{\circ} 49^{\prime} 08^{\prime \prime} \mathrm{S}, 41^{\circ} 04^{\prime} 15^{\prime \prime} \mathrm{W}, 24$ abr. 2010 (fl.),

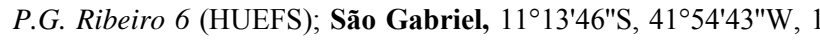
abr. 2009 (fr.) R.F. Machado et al. 67 (HUEFS).

Centrosema schottii se diferencia das demais espécies que ocorrem na Bahia pelos folíolos triangulares com margens sinuosas e base hastada. Além disso, apresenta flores grandes (2,7-5,2 cm compr.), com pétalas lilás e faixas brancas ao longo do estandarte, e frutos grandes e largos $(8,5-13,5 \times 6-9 \mathrm{~cm})$.

13. Centrosema sericiflorum K.L.Barreto \& L.P. Queiroz, Syst. Bot. 43(4): 980. 2018.

Figuras 3S, 7 e 14.

Trepadeira lenhosa, volúvel, ramos jovens, pecíolo e raque pubescentes, tricomas curtos e ferrugíneos. Estípulas ca. $7 \times 1,5 \mathrm{~mm}$, oval-triangulares, acuminadas, face externa serícea, persistentes. Folhas 14-15 cm compr., pinadas; pecíolo 5-5,3 cm compr.; raque $1-1,2 \mathrm{~cm}$ compr.; estipelas $5-6 \times 0,3-0,5 \mathrm{~mm}$, linear-triangulares, face externa pilosa; folíolos 3 , coriáceos, 7,5-8 ×6,3-6,8 cm, elípticos, ápice obtuso, base obtusa, os laterais ligeiramente assimétricos, face adaxial esparsamente pilosa, face abaxial pubescente, venação reticulada, 7 ou 8 pares de nervuras secundárias. Pseudorracemos ca. 8,3 cm compr., mais curtos que a folha adjacente; brácteas e bractéolas seríceas, brácteas de segunda ordem ca. $5,1 \times 4 \mathrm{~mm}$, oval-lanceoladas, bractéolas ca. $12,2 \times 8 \mathrm{~mm}$, elípticooblongas, assimétricas; pedicelos ca. 0,7 cm compr. Flores roxas, ca. $4 \mathrm{~cm}$ compr.; cálice ca. $14 \mathrm{~mm}$ compr., tubo ca. $7 \times 11 \mathrm{~mm}$, face externa serícea, tricomas finos, adpressos e ferrugíneos, face interna glabra, 4 lacínias, a superior ca. $8,5 \mathrm{~mm}$ compr., as laterais ca. $7 \mathrm{~mm}$ compr., a inferior ca. $6 \mathrm{~mm}$ compr., bífida; estandarte ca. $3,4 \times 3,7 \mathrm{~cm}$, orbicular, revoluto, face externa serícea, face interna glabrescente, com calcar inconspícuo; alas falcadas, onduladas, ca. $3 \mathrm{~cm}$ compr.; pétalas da carena ca. 2,3 3 1,3 cm, face externa pilosa, face interna glabrescente; androceu ca. 3,5 cm compr., glabrescente, bainha estaminal ca. $2,5 \mathrm{~cm}$ compr., filetes livres por ca. $10 \mathrm{~mm}$ compr., anteras ca. $1,8 \times 1 \mathrm{~mm}$, oblongoelípticas; pistilo ca. 1,8 cm compr., ovário ca. 1,5 × 1,8 $\mathrm{mm}$, séssil, piloso, estilete $0,3-1,3 \mathrm{~cm}$ compr., pubérulo, estigma capitado e ciliado. [Frutos não vistos].

Endêmica da Bahia. D7: caatinga arbustiva, geralmente em fragmentos de áreas abertas e secas, sobre substratos argilosos. Floresce em junho e julho.

Material selecionado - Bonito, $11^{\circ} 43^{\prime} 15^{\prime \prime} \mathrm{S}, 40^{\circ} 24^{\prime} 28^{\prime \prime} \mathrm{W}, 19$ jul. 1998 (fl.), L.P. Félix \& G. Trajano 8689 (HST); Morro do Chapéu, assentamento Olhos d'água, ca. $4 \mathrm{~km} \mathrm{SE}$ da rodovia BA-144 (sentido Utinga), entrando ca. $32 \mathrm{~km} \mathrm{~S}$ de Morro do Chapéu, em frente à entrada para Alto da MR, 11 $500^{\prime} 53^{\prime \prime} \mathrm{S}, 41^{\circ} 11^{\prime} 3^{\prime \prime} \mathrm{W}, 4$ jun. 2015 (fl.), L.P. Queiroz et al. 16129 (HUEFS).

Centrosema sericiflorum caracteriza-se pelos ramos rampuberulentos, folíolos coriáceos com face abaxial pubescente, brácteas, bractéolas, flores e cálice seríceos e ferrugíneos, calcar inconspícuo, estigma capitado e disco nectarífero lobado. Todos esses caracteres diferenciam esta espécie das demais do gênero, compartilhando a presença de ramos lenhosos e o indumento seríceo e ferrugíneo com $C$. vetulum Mart. ex Benth.

14. Centrosema venosum Mart. ex Benth. in Martius, Fl. Bras. 15(1B): 133. 1859.

Figuras 2E, 3T, 4E, F e 14.

Erva prostrada ou trepadeira volúvel, 1,5-3 m alt.; ramos jovens, pecíolo e raque glabrescentes. Estípulas 2,5-6 × 1,2-3 mm, oval-lanceoladas, acuminadas ou agudas, face externa pilosa, persistentes. Folhas 4,126,5 cm compr., pinadas; pecíolo 0,6-10,7 cm compr.; raque ausente; estipelas $1,3-5 \times 0,5-2 \mathrm{~mm}$, setiformetriangulares, face externa esparsamente pilosa, caducas; folíolos 3- ou 5-digitados, cartáceos, (3,5-)4,5-23,6 $\times$ 0,2-1,5 cm, geralmente lanceolados, raramente elípticos, ápice obtuso ou mucronado, base aguda, os laterais ligeiramente assimétricos, face adaxial esparsamente pilosa, tricomas sinuosos, face abaxial pilosa, tricomas setiformes, venação reticulada proeminentes em ambas as faces, 6-17(-20) pares de nervuras secundárias. Pseudorracemos 3,4-8 cm compr., mais curtos que a folha adjacente; brácteas e bractéolas esparsamente pilosas, brácteas de segunda ordem 2-9 × 1,2-4 mm, oval-lanceoladas, geralmente suborbiculares, bractéolas 5-17 × 2-6,5 mm, elípticooblongas, assimétricas; pedicelos 0,5-2,3 cm compr. Flores lilás, 3-6,5 cm compr.; cálice 12-32 mm compr., tubo 4-6 $\times 4-8 \mathrm{~mm}$, face externa pilosa, tricomas finos e eretos, face interna pilosa a glabrescente, lacínias 4 , a 


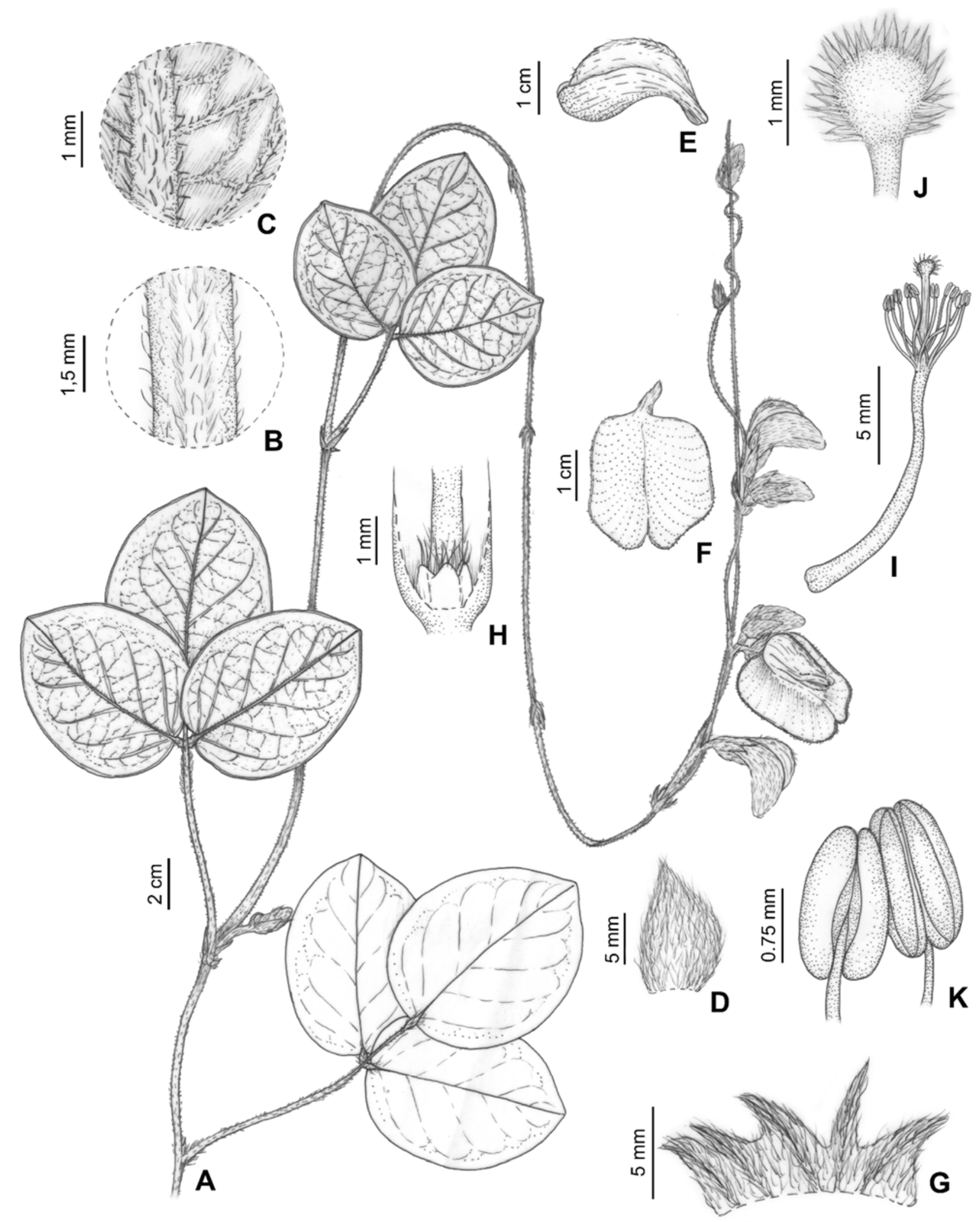

Figura 7. Centrosema sericiflorum: A- ramo reprodutivo; B- detalhe do ramo mostrando indumento; C- detalhe do folíolo abaxialmente; D- bractéola, face abaxial; E- pétala da ala e da carena; F- pétala do estandarte; G- cálice, face abaxial; H- flor internamente, mostrando o disco nectarífero lobado na base do pistilo; I- androceu, com porção superior do estilete no centro; J- estigma capitado e ciliado; K- anteras. (Desenhado por Lucas C. Marinho: Félix 8689). 


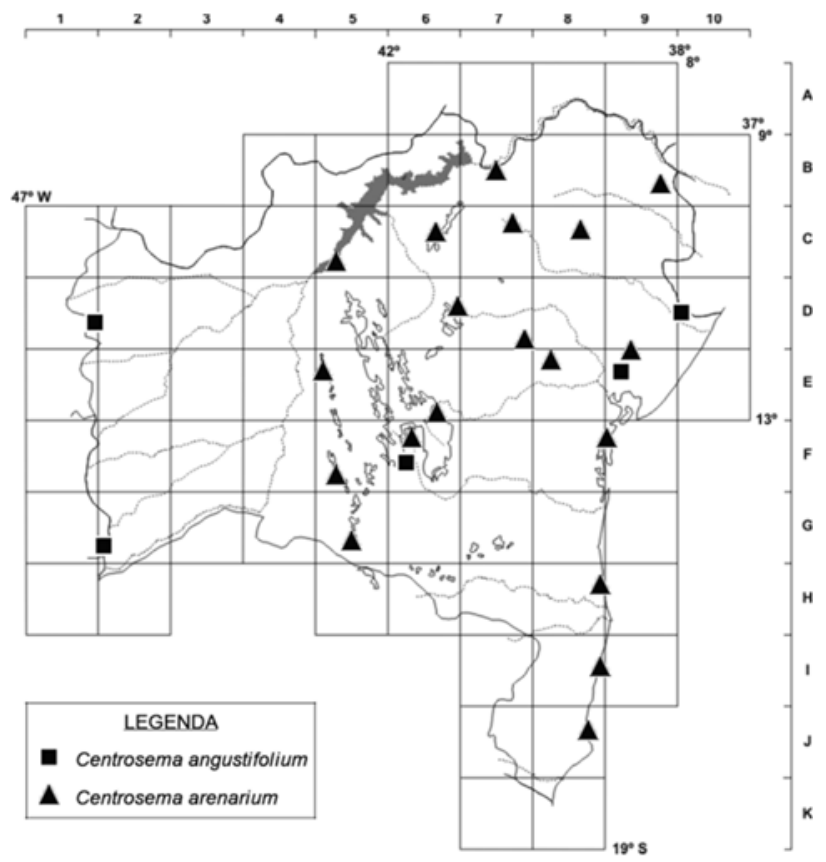

Figura 8. Distribuição de Centrosema angustifolium e C. arenarium no estado da Bahia.

superior $8-15 \mathrm{~mm}$ compr., reta, as laterais $3-9 \mathrm{~mm}$ compr., a inferior 3-9 mm compr., bífida; estandarte 2 $3,7 \times 1,3-3,6 \mathrm{~cm}$, orbicular, face externa pubescente, face interna glabrescente, calcar 2-4 mm compr.; alas falcadas, onduladas 1,7-2,8 cm compr.; pétalas da carena $1,7-2,6 \times 5-13,5 \mathrm{~cm}$, face externa pilosa, face interna esparsamente pilosa; androceu $2,1-3,3 \mathrm{~cm}$ compr., glabrescente, bainha estaminal 1,7-2,7 cm compr., filetes livres por 3-7 mm compr., anteras 1-1,5 $\times 0,6-1,2 \mathrm{~mm}$, oblongo-elípticas; pistilo $1,5-3,1 \mathrm{~cm}$ compr., ovário 9-16 × 0,6-1 mm, séssil, pubescente a piloso, estilete $0,6-1,5 \mathrm{~cm}$ compr., piloso a pubescente,

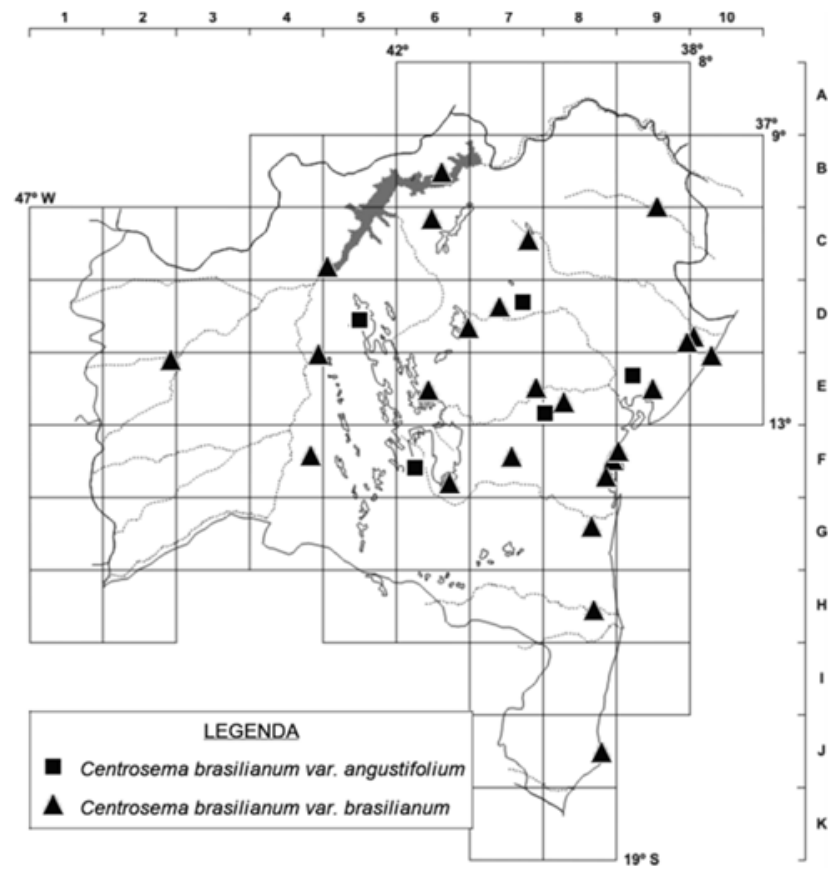

Figura 9. Distribuição de Centrosema brasilianum var. angustifolium e C. brasilianum var. brasilianum no estado da Bahia.

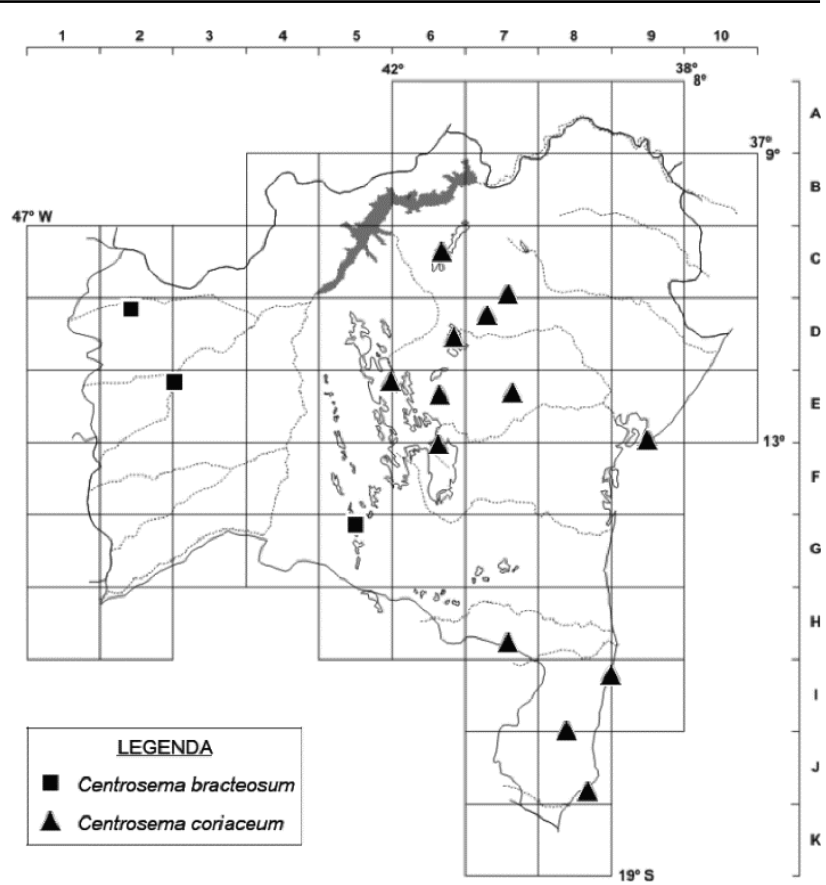

Figura 10. Distribuição de Centrosema bracteosum e C. coriaceum no estado da Bahia.

estigma truncado e ciliado. Legumes 7,5-12 $\times 0,4-0,7$ $\mathrm{cm}$, retos, rostro $0,7-1,3 \mathrm{~cm}$ compr., margens lisas ou onduladas, base aguda, valvas castanho-claras, pilosas; sementes 4-8 × 3-4 × 1,7-2,7 mm, oblongas ou orbiculares, testa coriácea, castanho-escura, hilo $1-1,2$ mm compr., elíptico.

Ocorre no norte da Colômbia, Venezuela, sul do Equador e Brasil (estados do Bahia, Goiás, Minas Gerais e Pará) (Schultze-Kraft et al. 1990; Aymard et al. 1999). D1, D2, D6, E2, F1/2, F3, F6 e G5: cerrados e campos rupestres, em solos arenosos. Floresce entre março e novembro e frutifica entre outubro e janeiro. A

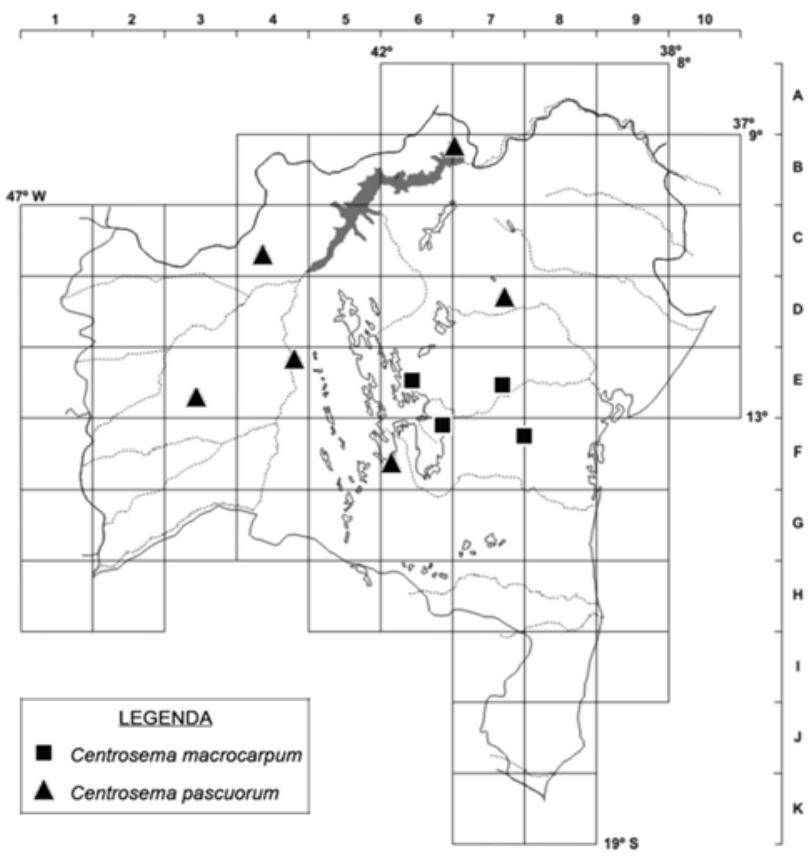

Figura 11. Distribuição de Centrosema macrocarpum e $C$. pascuorum no estado da Bahia. 


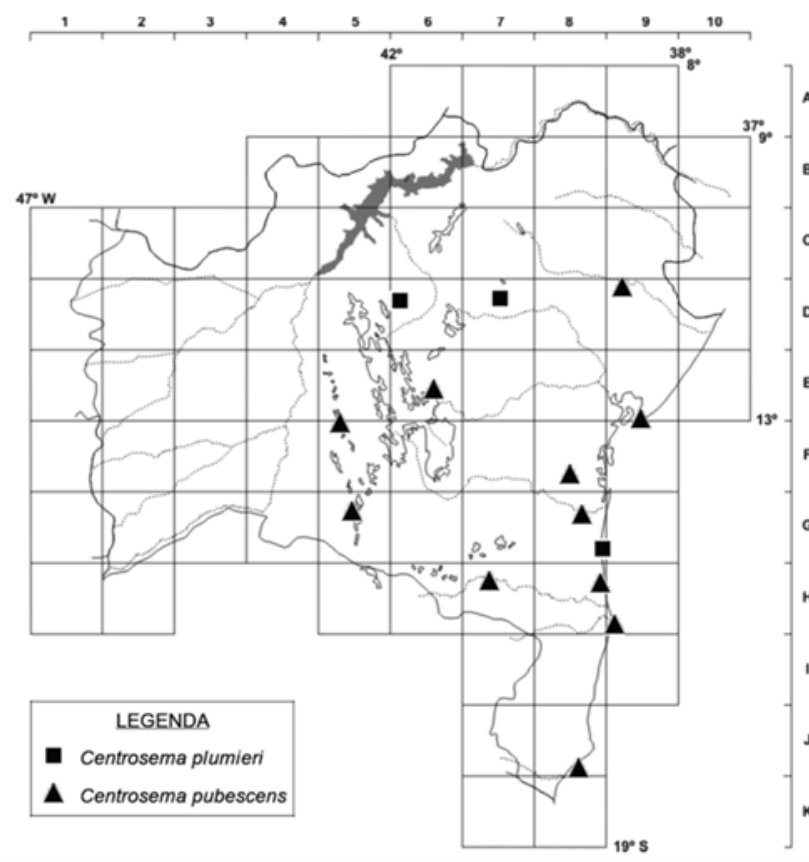

Figura 12. Distribuição de Centrosema plumieri e C. pubescens no estado da Bahia.

antese tem início por volta das 6:00 e as flores se mantêm abertas até aproximadamente às 17:00.

Material selecionado - Abaíra, caminho Capão, $13^{\circ} 19^{\prime} \mathrm{S}$, 41 ${ }^{\circ} 51^{\prime} \mathrm{W}, 6$ nov. 1993 (fl.), W. Ganev 2422 (HUEFS); Barreiras, $11^{\circ} 37^{\prime} 18^{\prime \prime} \mathrm{S}, 46^{\circ} 02^{\prime} 30^{\prime \prime W}$, s.d. (fl.), A. Cotrim et al. 1510 (HUEFS); Caetité, $6 \mathrm{~km}$ ao sul de Caetité na estrada para Brejinho das Ametistas, $14^{\circ} 07^{\prime} 47^{\prime \prime} \mathrm{S}, 42^{\circ} 30^{\prime} 15^{\prime \prime} \mathrm{W}, 10$ jan. 2006 (fl., fr., bot.), T.S.

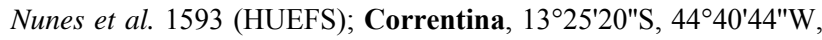
31 out. 2009 (fl.), J.G. Freitas et al. 562 (HUEFS); 21 dez. 1984 (fl.), G.P. Lewis et al. 7420 (HUEFS); Formosa do Rio Preto, próximo à fazenda Riachão, $11^{\circ} 06^{\prime} 50^{\prime \prime} \mathrm{S}, 45^{\circ} 28^{\prime} 20^{\prime \prime} \mathrm{W}, 2$ maio 2009 (fl., fr.), L.P. Queiroz et al. 14475 (HUEFS); Jaborandi, 133' $10^{\prime \prime} \mathrm{S}, 4^{\circ} 25^{\prime} 57^{\prime \prime} \mathrm{W}$,

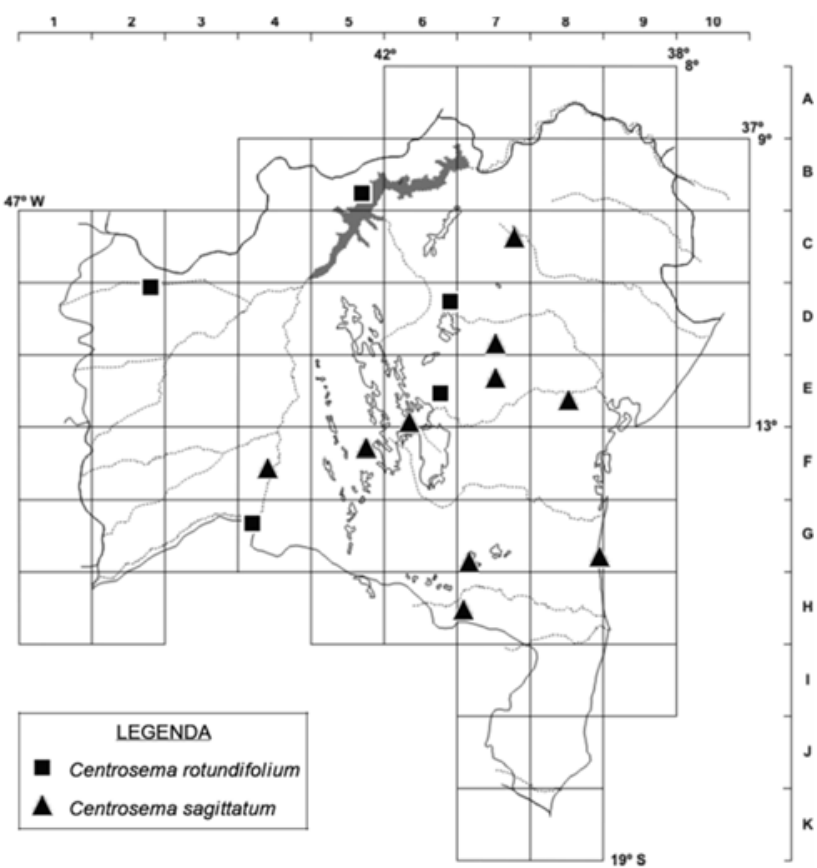

Figura 13. Distribuição de Centrosema rotundifolium e C. sagittatum no estado da Bahia.

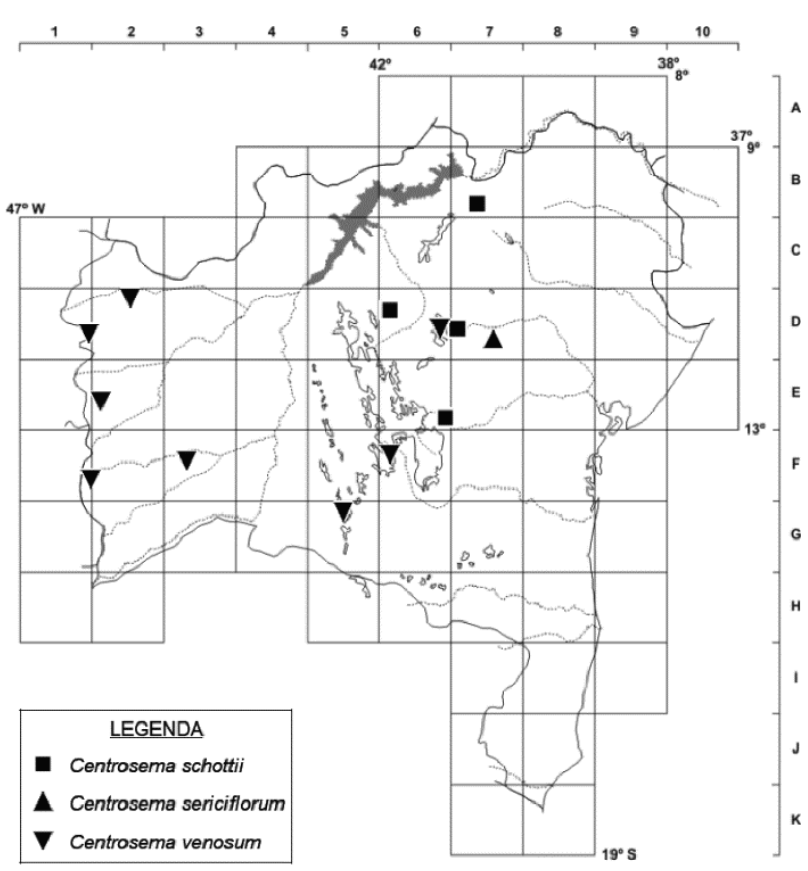

Figura 14. Distribuição de Centrosema schottii, C. sericiflorum e C. venosum no estado da Bahia.

13 abr. 2005 (fl., fr.), L.P. Queiroz et al. 10273 (HUEFS); Morro do Chapéu, $11^{\circ} 33^{\prime} 00^{\prime \prime S}, 41^{\circ} 03^{\prime} 00^{\prime \prime} \mathrm{W}, 5$ jan. 2005 (fl., bot.), J.G.A. Nascimento \& M.C. Machado 250 (HUEFS); Piatã, 1309'07"S, 4146'39"W, 21 dez. 1984 (fl.), G.P. Lewis et al. 7420 (HUEFS); Roda Velha, $12^{\circ} 33^{\prime}$ S, $45^{\circ} 52^{\prime}$ W, 9 out. 1976 (bot., fl.), G. Hatschbach 39089 (MBM); São Desidério, $13^{\circ} 41^{\prime} \mathrm{S}, 4^{\circ} 01^{\prime} \mathrm{W}, 15$ jun. 1983 (fl.), L. Coradin et al. 5698 (CEPEC).

Centrosema venosum pode ser reconhecida pelas folhas digitadas 3- ou 5-folioladas, folíolos geralmente lanceolados, raramente elípticos, com ambas as faces apresentando nervuras proeminentes, e cálice com lacínia superior não curvada. É morfologicamente semelhante a C. bracteosum, da qual se diferencia pelos folíolos geralmente lanceolados (vs. obovados ou elípticos em $C$. bracteosum), lacínias do cálice retas (vs. curvadas), além das nervuras proeminentes (vs. pouco proeminentes) em ambas as faces. As duas espécies também possuem ecologia semelhante e ocorrem com maior frequência em áreas de savana (Schultze-Kraft et al. 1990).

15.Centrosema virginianum (L.) Benth., Comm. Legum. Gen.: 56. 1837.

Figuras 2F-H, 3U e 15.

Trepadeira herbácea, volúvel, ou erva rasteira, ca. 1,5 m alt.; ramos jovens, pecíolo e raque, pubescentes a glabrescentes, tricomas longos, sinuosos e adpressos. Estípulas 3-5 × 1-2 mm, oval-triangulares, acuminadas, face externa pilosa, tricomas longos e finos, persistentes. Folhas 5-14,3 cm compr., pinadas; pecíolo 1,8-5 cm compr.; raque 0,5-1,8 cm compr.; estipelas 3-6 × 0,1-0,8 mm, setiformes, face externa pilosa, com tricomas curtos e finos, rígidas, persistentes; folíolos 3, membranáceos a papiráceos, 2,5-9,5 × 1,2$5,1 \mathrm{~cm}$, elípticos a ovais, ápice agudo, geralmente mucronado, base obtusa, os laterais ligeiramente 
assimétricos, ambas as faces pubescentes a glabras, venação reticulada, 5-12 pares de nervuras secundárias. Pseudorracemos 3,1-7,2 cm compr., mais curtos que a folha adjacente; brácteas e bractéolas pilosas, brácteas de segunda ordem 2-5 $\times 1,2-3 \mathrm{~mm}$, oval-orbiculares, bractéolas 5-8 $\times 2-4 \mathrm{~mm}$, elíptico-oblongas, assimétricas; pedicelos 0,4-1,1 cm compr. Flores lilás, 2,1-5,8 cm compr.; cálice 6-11,5 mm compr., tubo 3-4 $\times$ 3-5 mm, face externa pilosa, tricomas finos e longos, face interna pilosa a glabrescente, lacínias 4 , a superior 5-9 mm compr., as laterais 4,5-10 mm compr., a inferior 5-9 mm compr., bífida; estandarte 1,3-2 × 1,2-1,9 cm, suborbicular, face externa pubescente, face interna glabrescente, calcar 1-2 mm compr.; alas falcadas, onduladas 1,2-1,6 cm compr.; pétalas da carena 1,3-2,4 $\times 0,7-1 \mathrm{~cm}$, face externa esparsamente pilosa, face interna glabrescente; androceu 1,5-2,7 cm compr., glabrescente, bainha estaminal (10-)1,4-2,2 cm compr., filetes livres por 3-5 mm compr., anteras 0,8-1,5 × 0,81,1 mm, oblongo-elípticas; pistilo 1,1-2,1 cm compr., ovário 7-12 × 0,3-1 mm, séssil, pubérulo, estilete $(0,3-$ )0,4-0,9 cm compr., pubérulo, estigma truncado e ciliado. Legumes 6,5-13,4 × 0,3-0,6 cm, retos, estreitos, rostro 1,4-1,8 cm compr., margens retas, base aguda, valvas castanho-claras a vináceas, pubérulas, tricomas curtos e adpressos; sementes 3-5 × 2-3 × 1,3-1,9 mm, cilíndricas ou oblongas, testa coriácea, castanho-escura ou castanhoclara, hilo 1,1-1,5 mm compr., oblongo.

Amplamente distribuída na região neotropical, desde o leste dos EUA até a Argentina (Williams \& Clements et al. 1990). No Brasil, distribui-se em quase todos os estados (Schultze-Kraft et al. 1990). C5, C7, C8, D6, D7, D8, E2/3, E6, E7, E8, E9, F3, F4, F5, F6, F7, F8, G3, G7, G8, H8, I8 e J8: caatingas, cerrados, florestas ombrófilas e estacionais, restingas e áreas antropizadas. Floresce e frutifica entre janeiro e agosto. A antese tem

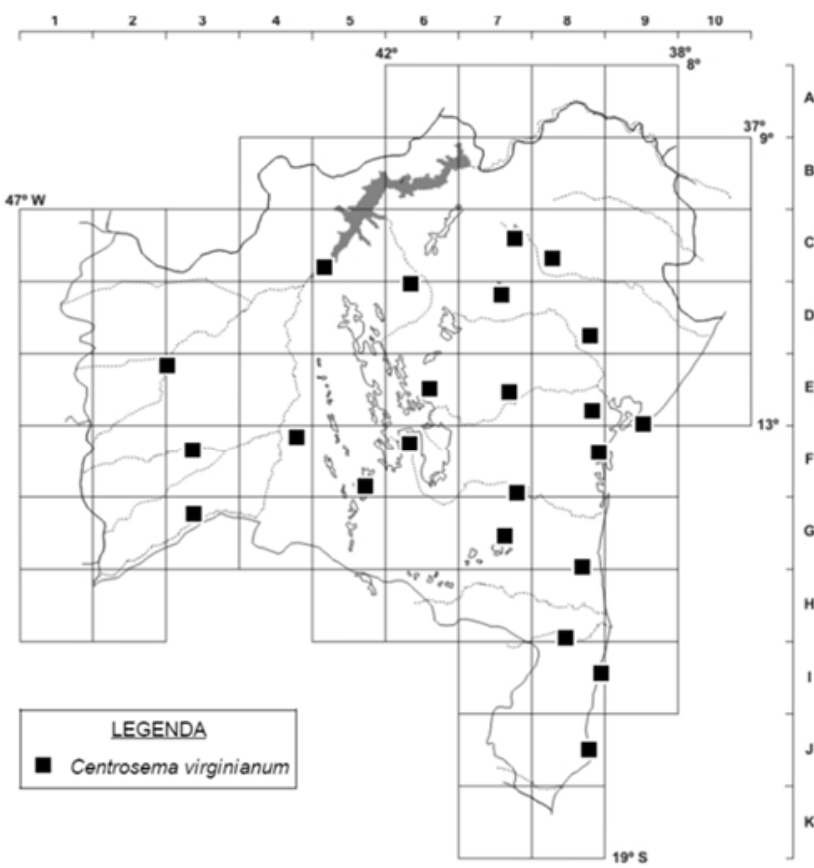

Figura 15. Distribuição de Centrosema virginianum no estado da Bahia. início por volta das 6:00 e as flores se mantêm abertas até aproximadamente às 17:00.

Material selecionado - Abaíra, 1314'59"S, 4139'49"W, 26 set. 1992 (fl., fr.), W. Ganev s.n. (HUEFS 13715); Alcobaça, 17³0'S, $39^{\circ} 13^{\prime} \mathrm{W}, 8$ dez. 1981 (fl.), G.P. Lewis \& A.M. Carvalho s.n. (CEPEC 30122); Anagé, $11^{\circ} 23^{\prime} \mathrm{S}, 40^{\circ} 45^{\prime} \mathrm{W}, 14$ maio 1983 (fl.), fr.), G. Hatschbach 46355 (MBM); Anguera, 12 ${ }^{\circ} 16^{\prime} \mathrm{S}, 39^{\circ} 02^{\prime} \mathrm{W}, 15$ set. 1996 (fl.), E. Melo et al. 1712 (HUEFS); Barra, Caminho para Coxos, $10^{\circ} 48^{\prime} \mathrm{S}, 42^{\circ} 50^{\prime} \mathrm{W}, 25$ fev. 1997 (fl., fr.), L.P. Queiroz et al. 4843 (HUEFS, MBM); Barreiras, 1209'10"S, 44'59'24"W, 29 set. 1978 (fr.), L. Coradin et al. 1199 (RB); Boa Nova, 1421'46"S, 40¹2'28"W, s.d., W.W. Thomas et al. 12227 (CEPEC); Bom Jesus da Lapa, $13^{\circ} 09^{\prime}$ S, $43^{\circ} 13^{\prime} \mathrm{W}, 500 \mathrm{~m}$ s.n.m, 17 abr. 1980 (fl., fr.), R.M. Harley 21445 (CEPEC); Buerarema, 1457'34"S, 39¹7'58"W, 16 jul. 1980 (fl.), L. Coradin et al. 2894 (HUEFS); Cachoeira, Barragem de Bananeiras, $12^{\circ} 32^{\prime} \mathrm{S}, 39^{\circ} 05^{\prime} \mathrm{W}, 120$ m s.n.m., 10 jul. 1980 (fl., fr.), Grupo Pedra do Cavalo 378 (CEPEC); Caen, $11^{\circ} 11^{\prime} \mathrm{S}, 40^{\circ} 25^{\prime} \mathrm{W}, 22$ ago. 1993 (fl.), L.P. Queiroz \& N.S. Nascimento 3551 (CEPEC, HUEFS, MBM); Caetité, arredores da área de preservação da INB (Indústria Nucleares do Brasil), 1350"27"S, 42¹6'21"W, 9 abr. 2010 (fr.), J.L. Paixão et al. 1665 (HUEFS); Cocos, trilha na beira da estrada de chão que liga Cocos a Minas Gerais, $14^{\circ} 14^{\prime} 08^{\prime \prime} \mathrm{S}, 44^{\circ} 37^{\prime} 02^{\prime \prime} \mathrm{W}, 9 \mathrm{abr}$. 2005 (bot., fl.), S.F. Conceição et al. 182 HUEFS); Conceição do Almeida, 1246'46"S, 39¹0'11"W, 24 jul. 1980 (fl., fr.), L. Coradin et al. 3377 (HUEFS); Contendas do Sincorá, $13^{\circ} 45^{\prime} 47^{\prime \prime} \mathrm{S}, 41^{\circ} 02^{\prime 2} 7^{\prime \prime} \mathrm{W}$, 28 fev. 2000 (fl., fr.), M.M. Silva et al. 314 (HUEFS); Correntina, ao lado do rio Corrente, $13^{\circ} 20^{\prime} \mathrm{S}, 44^{\circ} 38^{\prime} \mathrm{W}, 23$ abr. 1980 (fl., fr.), R.M. Harley 21643 (CEPEC); Cruz das Almas, $12^{\circ} 39^{\prime} 40^{\prime \prime} \mathrm{S}, 39^{\circ} 05^{\prime} 53^{\prime \prime} \mathrm{W}$, 30 jun. 2008 (fl., fr.), C.S. Machado 33 (HUEFS); Entre Rios, $12^{\circ} 03^{\prime} 00^{\prime \prime S}, 38^{\circ} 00^{\prime} 00^{\prime \prime W}, 25$ ago. 2010 (fl.), A.V. Popovkin 734 (HUEFS); Feira de Santana, Campus da UEFS, atrás da Biblioteca, $12^{\circ} 16^{\prime} 01 " \mathrm{~S}, 38^{\circ} 58^{\prime} 01^{\prime \prime W}, 25$ maio 1983 (fr.), L.R. Noblick 2686 (HUEFS); Iaçu, fazenda Suibra, $18 \mathrm{~km}$ a leste da cidade, seguindo a ferrovia, $12^{\circ} 43^{\prime} \mathrm{S}, 40^{\circ} 07^{\prime} \mathrm{W}, 12$ mar. 1985 (fl., fr.), L.R. Noblick 3590 (CEPEC, HRB); Ichu, fazenda Jitaí, $11^{\circ} 45^{\prime} \mathrm{S}, 39^{\circ} 12^{\prime} \mathrm{W}, 27$ jul. 2001 (fl., fr.), A.S. Carneiro 3 (HUEFS, UFP); Ipecaetá, fazenda Riachão, $12^{\circ} 20^{\prime} \mathrm{S}, 39^{\circ} 17^{\prime} \mathrm{W}, 14$ ago. 1985 (fl.), L.R. Noblick \& G.C. Lôbo 4317 (CEPEC, HUEFS); Ipirá, fazenda Mucambo, $12^{\circ} 10^{\prime} 01 " \mathrm{~S}$, 3944'00"W, 30 maio 1985 (fl.), B.C. Bastos s.n. (BAH 6710); Iramaia, fazenda Leopoldina, $13^{\circ} 33^{\prime} \mathrm{S}, 40^{\circ} 43^{\prime} \mathrm{W}, 4$ abr. 1984 (fl., fr.), J.C.A. Lima \& L.C. Oliveira-Filho 107 (HRB, RB); Itaberaba, fazenda Morro de Pedra, 12³1'39"S, 40¹8'25"W, 6 jun. 1983 (fl.), E.L.P.G. Oliveira s.n. (BAH 4588); Itaetê, $12^{\circ} 59^{\prime} 12^{\prime \prime} \mathrm{S}, 40^{\circ} 58^{\prime} 20^{\prime \prime} \mathrm{W}$, 13 abr. 2001 (fl.), D.M. Loureiro et al. 112 (ALCB); Itapebi, $15^{\circ} 57^{\prime} 03^{\prime \prime S}, 39^{\circ} 32^{\prime} 02^{\prime \prime W}, 16$ jul. 1980 (fl., fr.), L. Coradin et al. 2927 (HUEFS); Itiúba, fazenda Calderãozinho, 1040'S, 3943'W, 21 fev. 1974 (fl., bot.), R.M. Harley 16283 (CEPEC); Ituaçu, 1308'00"S, 41²8'33"W, 22 dez. 1983 (fl.), E.P. Gouveia s.n. (ALCB 23221); Jacobina, fazenda Brejo Novo, $11^{\circ} 05^{\prime} \mathrm{S}, 40^{\circ} 40^{\prime} \mathrm{W}$, s.d. (fl., fr.), M.M. Arbo et al. 7400 (CEPEC); Jaguarari, 10¹9'S, 40¹0'W, 25 jun. 1983 (fl., fr.), L. Coradin et al. 6000 (CEPEC, HUEFS, NY); Jequié, 1356'22"S, 40¹1'27"W, 835 m s.n.m, s.d. (fl., fr.), W.W. Thomas et al. 13574 (CEPEC); Macajuba, 1205'44"S, 40¹8'39"W, 26 jul. 2004 (fl.), L.P. Queiroz et al. 9228 (HUEFS); Maracás, 13²3'24"S, 40 18'08"W, 25 mar. 2008 (fl., fr.), S.C. Ferreira et al. 383 (HUEFS); Morro do Chapéu, margens do rio Ferro doido, 11³7'15"S, 4059'46"W, 3 mar. 1997 (fl.), E.N. Lughadha et al. 5991 (HUEFS); Mundo Novo, fazenda Jequitibá, $12^{\circ} 02^{\prime} \mathrm{S}, 40^{\circ} 29^{\prime} \mathrm{W}, 29$ jul. 2006 (fl.), P.A. Melo 82 (HUEFS); Poções, $14^{\circ} 31^{\prime} 47^{\prime \prime} \mathrm{S}, 40^{\circ} 21^{\prime} 54^{\prime \prime} \mathrm{W}, 5$ maio 
1978 (fl., fr.), S.A. Mori et al. 9541 (CEPEC); Porto Seguro, 16²6'S, 3903'W, 21 mar. 1974 (fl., fr.), R.M. Harley 17270 (CEPEC, RB); Riachão do Jacuípe, fazenda Várzea, $11^{\circ} 22^{\prime} \mathrm{S}, 39^{\circ} 49^{\prime} \mathrm{W}, 10$ jul. 1985 (fl., fr.), L.R. Noblick 4018 (HUEFS); Ruy Barbosa, fazenda Santa Maria, 12¹7'02"S, 40²9'37"W, 20 dez. 2004 (fl.), L.P. Queiroz et al. 9974 (HUEFS); Salvador, Parque Metropolitano de Pituaçu, 1258'21"S, 38²8'31"W, 19 out. 2004 (fl., fr.), E.P. Queiroz 2084 (ALCB); Santa Cruz Cabrália, Estação Ecológica do Pau-Brasil (ESPAB), 16²3'S, 3908'W, 28 jun. 1984 (fl., fr.), F.S. Santos 332 (CEPEC, HUEFS); Santo Amaro, 12³2'45"S, 3848'09"W, 22 nov. 1986 (fl., fr.), L.P. Queiroz et al. 1345 (HUEFS); São Gabriel, fazenda Boa Sorte, $11^{\circ} 01^{\prime} \mathrm{S}, 41^{\circ} 39^{\prime} \mathrm{W}, 5$ abr. 2009 (fl.), R.F. Machado et al. 185 (HUEFS); Saúde, $11^{\circ} 07^{\prime} \mathrm{S}, 40^{\circ} 27^{\prime} \mathrm{W}, 22$ jun. 1987 (fl.), L. Coradin et al. 7732 (HUEFS, RB); Seabra, 12²8'33"S, 41²3'33"W, 22 ago. 1981 (fl., fr.), L. Coradin et al. 4459 (HUEFS, RB); Senhor do Bonfim, $10^{\circ} 23^{\prime} 19^{\prime \prime S}, 40^{\circ} 13^{\prime} 24 " \mathrm{~W}, 29$ jul. 2005 (fl.), V.J. Santos et al. 462 (HUEFS); Tucano, Povoado de Bisamum, 1057'46"S, 38 47'13"W, s.d. (fl., fr.), G. Costa 370 (HUEFS); Valença, 13²2'14"S, 3904'22"W, 16 jul. 1980 (fl., fr.), L. Coradin et al. 2959 (HUEFS).

Centrosema virginianum é caracterizada pela presença de flores grandes (2,1-5,8 cm compr.) e lacínias do cálice uniformes, longas, maiores que as bractéolas, o que as torna visíveis até mesmo nos botões florais. É morfologicamente semelhante a $C$. brasilianum, da qual se diferencia pelas lacínias do cálice longas e lineares (vs. curtas em C. brasilianum).

\section{AgRAdecimentos}

Os autores agradecem aos curadores dos herbários visitados; Lucas Cardoso Marinho, pelas ilustrações e ajuda na edição das pranchas; Cristiane Snak, Domingos Cardosos, Réginald Hulhoven, Reinaldo Aguiar e Wallace São-Mateus, por cederem fotos utilizadas nas pranchas; Pétala Gomes Ribeiro e um revisor anônimo, por valiosas sugestões em uma versão anterior do manuscrito; o Programa de Pesquisa em Biodiversidade (PPBIO) do Semiárido, Sistema Nacional de Pesquisa em Biodiversidade (SISBIOTA CNPq 563084/20103/FAPESB PES0053/2011), PROTAX (CNPq 562354/2010-7) e REFLORA (CNPq 563546/20107/FAPESB PES0054/2011), pelo apoio financeiro.

\section{REFERÊNCIAS}

Amshoff, G.J.H. 1939. On the South American Papilionaceae. Mededeelingen van het Botanisch Museum en Herbarium van de Rijks Universiteit Utrecht 52: 1-78.
Aymard, G.A.; Cuello, N.L.; Berry, P.E.; Rudd, V.E.; Cowan, R.S.; Fantz, P.R.; Maxwell, R.H.; Stirton, C.H.; Poppendieck, H.; Lima, H.C.; Fortunato, R.H.; Stergios, B.; Enrich, N.X.; Neill, D.A.; Pennington, R.T. \& Gil, C. 1999. Fabaceae. In: P.E. Berry, K. Yatskievych \& B.K. Holst (eds), Flora of the Venezuelan Guayana. Vol. 5. Eriocaulaceae-Lentibulariaceae. Missouri Botanical Garden, Saint Louis, p. 231-433.

Barbosa-Fevereiro, V.P.B. 1977. Centrosema (A.P. de Candolle) Bentham do Brasil-Leguminosae-Faboideae. Rodriguésia 29: 159-203.

Bentham, G. 1837. Clitoria. In: G. Bentham (ed.), Commentationes de Leguminosarum Generibus. Typis J.B.Sollingeri, Vindobonae, p. $50-51$.

BFG - The Brazil Flora Group. 2015. Growing knowledge: an overview of seed plant diversity in Brazil. Rodriguésia 66: 10851113.

Cronquist, A. 1981. An Integrated System of Classification of Flowering Plants. Columbia University Press, New York.

Duno de Stefano, R.; Fantz, P.R. \& Fernández-Concha, G.C. 2008 Centrosema and Clitoria (Leguminosae: Papilionoideae: Phaseoleae: Clitoriinae) in the Mexican Yucatán Peninsula, including three lectotypifications. Vulpia 7: 1-15.

Flora do Brasil 2020, em construção. Jardim Botânico do Rio de Janeiro. Disponível em: < http://floradobrasil.jbrj.gov.br/ >. Acesso em: 7 nov. 2020.

Lackey, J. 1981. Tribe Phaseoleae. In: R.M. Polhill \& P.H. Raven (eds), Advances in Legume Systematics, Part 1. Royal Botanic Gardens, Kew, p. 301-327

LPWG - Legume Phylogeny Working Group. 2017. A new subfamily classification of the Leguminosae based on a taxonomically comprehensive phylogeny. Taxon 66: 44-77.

Queiroz, L.P. 2009. Leguminosas da Caatinga. Editora Universitária UEFS, Feira de Santana.

Schultze-Kraft, R.; Williams, R.J. \& Coradin, L. 1990. Biogeografia de Centrosema. In: R. Schultze-Kraft \& R.J. Clements (eds), Centrosema: Biology, Agronomy, and Utilization. Publicación CIAT 208. Centro Internacional de Agricultura Tropical, Cali, p. 29-76.

Schrire, B.D. 2005. Tribe Phaseoleae. In: G.P. Lewis, B. Schrire, B. Mackinder \& M. Lock (eds), Legumes of the World. Royal Botanic Gardens, Kew, p. 393-431.

Souza, V.C. 2019. Centrosema. In: Lista de Espécies da Flora do Brasil. Instituto de Pesquisa Jardim Botânico do Rio de Janeiro. Disponível em http://floradobrasil.jbrj.gov.br/jabot/floradobrasil; acesso em 25 maio 2019.

Williams, R.J. \& Clements, R.J. 1990. Taxonomy of Centrosema. In: R. Schultze-Kraft \& R.J. Clements (eds), Centrosema: Biology, Agronomy, and Utilization. Publicación CIAT 208. Centro Internacional de Agricultura Tropical, Cali, p. 1-27.

\title{
LISTA DE EXSICATAS
}

\begin{abstract}
Albuquerque, M. 2 (4); Almeida, M.N.F. s.n. BAH 2200 (5); Alunos da 2 série s.n. ALCB 1627 (4); Alunos da 3a série s.n. ALCB 1632 (9); Alunos de Bot. III t02 s.n. ALCB 67197 (4), s.n. ALCB 67208 (5); Amorim, A.M. 1790 (5), 2554 (15), 6918 (5); Anderson, W.R. 36585 (3), 37103 (15); Arbo, M.M. 5400 (5), 7188 (4), 7400 (15); Avena, C. s.n. BAH 5053 (4); Barbosa, M.M.S. s.n. BAH 6653 (4); Barreto, K.L. 28(2), 39 (4), 48 (7), 62 (4), 76 (1), 84 (12); Barreto, M.L. s.n. ALCB 61819 (4); Barreto, V. 131 (5); Bastos, A. 181 (15), s.n. BAH 2645 (9), s.n. HUEFS 42994 (4); Baumgratz, J.F.A. 147 (2); Bautista, H.P. 463 (5), 874 (4), 1031(11), 1179 (4), 1372 (9); Belém, R.P. 1727
\end{abstract}


(4), 1669 (8), 2363 (4), 2511 (4), 3593 (11); Blanchet, J.S. 2705 (10); Borba, E.L. 1947(2), 1958 (5), 2052 (5), 2198 (4); Borges, D.S.R. s.n. ALCB 26999 (15); Braga, N.M.P. 37 (4); Brito, H.S. 161 (9); Brito, J.C. 141 (5); Cahivo, S. 2 (4); Cardoso, D. 38 (15), 400 (5), 653 (5), 742 (11), 896 (9), 930 (2), 1109 (4), 2053 (15), 2087 (11), 2629 (4); Cardoso, P.H.C.B. 67 (5); Carneiro, A.S. 3, 21 (15); Carneiro, J. 1168 (4); Carneiro-Torres, D.S. 495 (2); Carvalho, A.M. 444 (4), 3811 (11), 6993 (15), 7024 (5), 7218 (4); Carvalho, C.A.L. 48 (15); Carvalho, P.D. 172 (15); Castro, R.M. 1265 (15); Cavalcanti, T.B. 296, 310 (2), 332 (1); Cerqueira, C.O. 13 (5), 25 (4); Conceição, A.A. 1970 (11), s.n. ALCB 40274 (10); Conceição, A.S. 65, 96 (4); Conceição, S.F. 155 (15), 182 (15); Coradin, L. 1150 (14), 1196 (2), 1199,1204 (15), 1211 (4), 2844 (8), 2857, 2866, 2878 (4), 2894 (15), 2920, 2922 (4), 2927 (15), 2930 (4), 2932 (8), 2939 (9), $2959,2978,3377$ (15), s.n. CEPEC 42127 (5), 4328, 4388 (4), 4421, 4435, 4440, 4443 (5), 4444 (6), 4459 (15), 4460, 4476, 4479 (5), 4533 (4), 4548,4799 (6), 5698 , 5701 (14), 6000 (15), 6089 (5), 6337, 6483, 6504, 7584, 7622, 7628, 7645, 7668 (4), 7669 (9), 7683 (4), 7702, 7732 (15), 7734 (2), 7969 (9), 8577, 8589, 8652, 8679 (4); Costa, A.L. s.n. ALCB 1635 (15), s.n. ALCB 1647 (8); Costa, C.F. s.n. BAH 1429 (9); Costa, G. 370 (15); Costa, J. 86 (15), 88 (4), 170 (15), 265 (4), 1285 (5), 1332 (4); Costa-Neto, E.M. 47 (4); Cotias, A.L. s.n. ALCB 72940 (4); Cotrim, A. 1510 (14); Daneu, L. 374 (5); Davidse, A. 11883 (5); Duarte, A.P. 5913 (5), 5965 (2), 9353 (5); Dutra, A.E. 30 (15); Eaton, A.A. 10066 (5); Equipe da Botânica s.n. ALCB 20906 (5); Euponino, A. 381 (4); Fahel, J. s.n. ALCB 1638 (15), s.n ALCB 1639 (15); Faria, G.A. 44 (4), 165 (9); Faria, S.M. 2259 (2); Félix, L.P. 7565 (2); s.n. EAN 6721, 8608 (5); Fernandes, A. s.n. EAC 3286 (15), s.n. EAC 3666 (14); Ferreira, J.L. 302 (4); Ferreira, M.S.G. BAH 4364 (9); Ferreira, S.C. 383 (15); Ferrucci, M.S. 1096 (5); Fiaschi, P. 2407 (5); Fierro, A.F. SPSF 80007 (4); Fioravanti, A.B. 2 (4); Fonseca, M.L. 3060 (1); Fonseca, W.N. 257 (15); Fonseca-Neto, F.P. 14 (4); Forzza, R.C. 1117 (2); Fotius, G. 4028 (12); França, F. 1421, 1473, 1531 (4), 2669 (5), 5143 (4), 5231,5827 (5); Freitas, J.G. 561 (3), 562 (14); Funch, R. 96 , 663 (4); Ganev, W. 137 (4), 1552 (2), 2327(5), 2422 (14), 2536, 2614 (14), s.n. HUEFS 13715 (15), s.n. HUEFS 13723, s.n. SP 358451 (14); Giulietti, A.M. 1877 (2); Gomes, F.S. 68, 223, 729 (4); Gonçalves, L.M.C. 179 (5); Gouveia, E.P. 5783 (15), s.n. ALCB 23090 (4); Groppo, M. 1065 (2); Gross, E. 17 (4), 24 (4); Grupo Pedra do Cavalo 198 (9), 378, 642 (15); Guedes, M.L. 2562 (4), 2720 (5), 2978,6618 (15), 9031 (5), 9343 (2), 9422 (4), 1063 (5), 11952 (4), s.n. ALCB 99560 (5), 11472 (4), 12176 (4), 13224, 13851 (4), 14111 (10), 14313 (15), 15033 (4), 16987 (5), 18152 (4), PCD 2720 (5), s.n. ALCB 1630 (11); Guimarães, E.F. 932 (15); Hage, J.L. 677 (8), 841 (4), $1005,1123,1506$ (8), 1683 (9), 2068 (8); Harley, R.M. 15990 (5), 16035 (2), 16283 (15), 16414, 16686 (2), 16686a (5), 17270 (15), 17293, 18457 (4), 18567 (5), 21303 (2), 21445, 21643 (15), 22154, 22347,26556 (4), 50384 (14), 53778 (10); Hatschbach, G. 39089 (14), 44219 (5), 46355 (15), 47037 (9), 47967 (5), 55175 (10), 56635 (2), 56935 (11), 62025 (3), 62983 (4), 67787 (2), 68454 (8), 71260,77880 (11); Irwin, H.S. 14854 (14); Jardim, J.G. 2007 (5); Jesus, N.G. 416, 1542 (4); Jost, T. 396, 404 (4); Junqueira, M.E.R. 7 (4), 69 (5); Kallunki, J. 381 (4); Labouriau, L.G. 12 (4); Lemos, M.J.S. 114 (2); Lewis, G.P. 704 (4), 760, 950 (5), 986 (15), 1890 (4), 1925 (7), 1991 (2), 7420 (14), s.n. CEPEC 30122 (15); Lima, H.C. 732,764 (5); Lima, J.C.A. 107 (4), 231 (5); Lima, J.L.S. 428 (4); HTSA 1813 (2); Loefgren, A. 918 (7); Loureiro, D.M. 112 (15); Lughadha, E.N. 5991 (15); Macedo, G.E.L. 1252 (15); Machado, C.S. 33 (15); Machado, R.F. 67 (12), 185, 526 (15); Martinelli, G. 5272 (5), 11058 (4); Martius, C.F.P. 2295 (10); Matos, E.N. FCO 8 (4), 25 (4), FCO 49 (8), 73 (9), 75, 82 (15), 98 (4), 191 (8), 192 (4), 462 (5), 1776 (5), 1822 (4), PCD 4496, PCD 4524 (2), s.n. HUEFS 180445 (2); Mattos-Silva, L.A. 802, 2062 (4), s.n. RB 207021 (2); Meireles, J.E. 656 (2); Melo, A.A. 248 (4); Melo, E. PCD 1201 (5), 1614 (4), 1712 (15), 4357 (4), 4521 (5), 4717 (10), 4957 (5), 6760 (4), 7422, 7473 (2), 7642 (5), 9978 (4); Melo, P.A. 82 (15); Mendes, M.S. 402 (2); Mendonça, R.C. 1434 (3); Meyer, P. (5); Miranda, A.M. 137 (2); Mori, S.A. 14275 (4), 9541 (15), 9929 (4); Moruz, C.V.A. s.n. BAH 8159 (5); Nascimento, A.F.S. 45 (4); Natividade, P.C. 11 (4), 12 (4), 16 (5); Neves, M.F. s.n. BAH 2202 (4); Noblick, L.R. 1167, 1526, s.n. ALCB 1641 (4), 1955, 2020 (15), 2135,2147 (4), 2686 (15), 2804 (5), 3560, 3590, 4018, 4302, 4317 (15), 4426 (4); Nogueira, T.F. 14 (4); Nolasco, A.P. 1 (4); Nunes, A.T. 125 (4); Nunes, T.S. 318 (8), 426, 428, 607 (4), 608, 1205 (5), 1455, 1571 (2), 1592 (3), 1593 (14), 1595 (2); Oliveira, E.L.P.G. s.n. BAH 4588 (15), s.n. BAH 2261 (9), s.n. BAH 8204 (4); Oliveira, F.A. 1 (4); Oliveira, R.P. 40 (4), s.n. ALCB 61500 (5); Orlandi, R.P. 240 (8), 288 (2), 474 (5), 240 (8); Nascimento, J.G.A. 77 (15), 142 (5), 250 (14); Nascimento, J.P.B. 6 (2); Neiva, A. s.n. SP 24051 (15); Neves, S.P.S. 86, 165 (5); Nunes, M.S. 35 (5); Paixão, J.L. 1665 (15); Pastore, J.F.B. 2081 (5); Pedralli, G. 2614 (5); Pereira, A. 337 (5); Pinheiro, R.S. 1584 , 2108 (4), 2230 (8); Pereira, V.S. 36 (5); Pinto, G.C.P. 11 (4), 313 (2), 342; 1182 (4), s.n. ALCB 1629 (11), s.n. ALCB 1633 (9), 1644 (5), s.n. ALCB 6218 (1), 31381 (2), 34281 (4), 42261 (1); Popovkin, A.V. 105 (4), 719 (4), s.n. HUEFS 165027 (15); Queiroz, E.P. 34, 35, 36 (4), 46 (5), 72 (4); 708 (5), 2084 (15); Queiroz, L.P. 1345 (15), 1685, 1696, 2441, 2541, 3192, 3516 (4), 3551, 3836 (15), 4030 (5), 4657 (4), 4843 (15), 4871 (4), 4896 (15), 5479 (5), 5484 (2), 6609 (10), 9023, 9228 (15), $9351(5), 9441$ (11), 9684 (4), 9974 (15), 10013 (11), 10032,10223 (4), 10273 (14), 10783 (5), 14475 (14), 14655 (4), 16129 (13); Ramalho, M. s.n. ALCB 75160 (4); Ramos, C.E. 304 (4); Rapini, A. 955 (5) 1471 (2); Ribeiro, P.G. 6 (12); Ribeiro-Filho, A.A. 55 (5); Rodarte, A.T. 101 (4); Roque, N. s.n. ALCB 3455 (5), 4496 (2), 4524 (4), s.n. ALCB 67715 (5), s.n. CEPEC 79173 (4); Ruschi, A. (5); Saar, E. 4604 (5); Salgado, O.A. 294 (7); Sano, P.T. 14472 (14); Santana, D.L. 354 (4), 702 (14); Sant'Ana, S.C. s.n. ALCB 4618 (8); Santos, A.K.A. 559, 609 (9); Santos, E.B. 63 (8); Santos, F.S. 332 (15); Santos, T.S. 724 (4); Santos, V.J. 462 (15), 551 (2); Scardino, L. 378 (15); Scariot, A.O. 447 (14); Selma, S. s.n. ALCB 19895 (9); Sena, T.S.N. 6 (2), s.n. MBM 215289 (4); Silva, E.B.M. 173 (5); Silva, G.P. 8403, 8475, s.n. HUEFS 193853 (2); Silva, M.M. 178 (4), 266,314 (15); Silva, S.B. 167 (3); Silva, T.A. HST 2323 (4); Siqueira-Filho, J.A. 1680 (4); Souza, C.S.D. 97 (4), 251 (4); Souza, E.B. 1396 (5); Souza, E.R. 686 (4); Souza, J.P. 9794 (4), 9841 (7); Sousa, L.A. 112 (5), 219 (2); Souza-Silva, P.F. 185 (2); Smith, N.P. 67 (5); Sobrinho, J.P.L. 7 (4); Soeiro, R. 4 (15), 3795 (4); Souza, I.M. s.n. HUEFS 180189 (5); Stannard, B. s.n. 92181 (4); Stradmann, M.T.S. 569 (5), 584 (9), 589 (4); Teixeira, A.F.R. 18 (4); Thomas, W.W. 10078 (15), (9), 13574 (15), 14136 (4), s.n. CEPEC 88727 (15); Torrend, P.C. s.n. ALCB 1631 (11); Vasconcelos, O.C.M. 1 (7); Viana, B.F. 91 (5), 99 (4); Vieira, R.F. 1098 (3), 1125 (3); Viollati, L.G. 157 (3). 